University of Massachusetts Amherst

ScholarWorks@UMass Amherst

Environmental Conservation Faculty Publication

Series

Environmental Conservation

2018

\title{
A landscape index of ecological integrity to inform landscape conservation
}

\author{
Kevin McGarigal \\ University of Massachusetts Amherst \\ Brad Compton \\ University of Massachusetts Amherst \\ Ethan Plunkett \\ University of Massachusetts Amherst \\ Bill DeLuca \\ University of Massachusetts Amherst \\ Joanna Grand \\ National Audubon Society
}

See next page for additional authors

Follow this and additional works at: https://scholarworks.umass.edu/nrc_faculty_pubs

Part of the Environmental Monitoring Commons, and the Natural Resources and Conservation Commons

\section{Recommended Citation}

McGarigal, Kevin; Compton, Brad; Plunkett, Ethan; DeLuca, Bill; Grand, Joanna; Ene, Eduard; and Jackson, Scott D., "A landscape index of ecological integrity to inform landscape conservation" (2018). Landscape Ecology. 402.

Retrieved from https://scholarworks.umass.edu/nrc_faculty_pubs/402

This Article is brought to you for free and open access by the Environmental Conservation at ScholarWorks@UMass Amherst. It has been accepted for inclusion in Environmental Conservation Faculty Publication Series by an authorized administrator of ScholarWorks@UMass Amherst. For more information, please contact scholarworks@library.umass.edu. 
Authors

Kevin McGarigal, Brad Compton, Ethan Plunkett, Bill DeLuca, Joanna Grand, Eduard Ene, and Scott D. Jackson 


\section{A landscape index of ecological integrity to inform landscape conservation}

Kevin McGarigal $^{\mathrm{a}}$, Bradley W. Compton ${ }^{\mathrm{a}}$, Ethan B. Plunkett ${ }^{\mathrm{a}}$, William V. DeLuca ${ }^{\mathrm{a}}$, Joanna

Grand $^{\mathrm{a} 1}$, Eduard Ene ${ }^{\mathrm{a} 2}$, and Scott D. Jackson ${ }^{\mathrm{a}}$

${ }^{a}$ Department of Environmental Conservation, University of Massachusetts, Amherst, MA 01003, USA

Kevin McGarigal (Corresponding author)

email: mcgarigalk@eco.umass.edu

phone: 413-577-0655/fax: 413-545-4358

Bradley W. Compton, bcompton@eco.umass.edu

Ethan B. Plunkett, eplunkett@eco.umass.edu

William V. DeLuca, wdeluca@eco.umass.edu

Joanna Grand, jgrand@audubon.org

Eduard Ene, gispro@gmail.com

Scott D. Jackson, sjackson@umass.edu

Date of the manuscript: May 29, 2018

Manuscript word count (including abstract, text, tables, and captions): 9,899

${ }^{1}$ Science Division, National Audubon Society, Northampton, MA 01060, USA

2Eco-logica Software Solutions, Waterloo, ON N2T2M7, Canada 


\begin{abstract}
Context. Conservation planning is increasingly using "coarse filters" based on the idea of conserving "nature's stage". One such approach is based on ecosystems and the concept of ecological integrity, although myriad ways exist to measure ecological integrity.

5 Objectives. To describe our ecosystem-based index of ecological integrity (IEI) and its derivative index of ecological impact (ecoImpact), and illustrate their applications for conservation assessment and planning in the northeastern United States.

Methods. We characterized the biophysical setting of the landscape at the $30 \mathrm{~m}$ cell resolution using a parsimonious suite of settings variables. Based on these settings variables and mapped

10 ecosystems, we computed a suite of anthropogenic stressor metrics reflecting intactness (i.e., freedom from anthropogenic stressors) and resiliency metrics (i.e., connectivity to similar neighboring ecological settings), quantile-rescaled them by ecosystem and geographic extent, and combined them in a weighted linear model to create IEI. We used the change in IEI over time under a land use scenario to compute ecoImpact.
\end{abstract}

15 Results. We illustrated the calculation of IEI and ecoImpact to compare the ecological integrity consequences of a 70-year projection of urban growth to an alternative scenario involving securing a network of conservation core areas (reserves) from future development.

Conclusions. IEI and ecoImpact offer an effective way to assess ecological integrity across the landscape and examine the potential ecological consequences of alternative land use and land 20 cover scenarios to inform conservation decision making. Key words: landscape pattern; landscape metrics; ecological assessment; conservation planning; landscape conservation design; coarse filter 


\section{Introduction}

Unrelenting human demand for commodities and services from ecosystems raises questions

25 of limits and sustainability. Many scientists believe that the earth is facing another mass extinction as a consequence (Pimm et al 1995; Ceballos et al 2015). Indeed, current global extinction rates for animals and plants are at least 100 times higher than the background rate in the fossil record (Ceballos et al 2015). A number of factors have been implicated as key drivers of this global biodiversity crisis, but chief among them is anthropogenic habitat loss and

30 fragmentation (Sala et al 2000, Pereira et al 2010; Haddad et al 2015, Newbold et al 2015). In response, land use planners and conservationists are seeking better ways to proactively conserve the most significant natural areas before they are lost or irreversibly degraded, but it is difficult to prioritize areas that are in the greatest need of protection, or determine which ones provide the greatest ecological value for the cost of protection. Analyzing a landscape’s

35 ecological/biodiversity value requires integrating vast amounts of site-specific information over varying spatial scales. Conservation organizations, which collectively spend billions of dollars each year to protect and connect natural areas (Lerner et al 2007), increasingly need tools to effectively target conservation.

To meet the growing need for targeting conservation action, a variety of approaches have

40 been developed for evaluating the human footprint (e.g., Sanderson et al 2002, Theobald 2013, Venter et al 2016) and selecting lands and waters for conservation protection (e.g., Williams et al 2002; Ortega-Huerta and Peterson 2004, Belote et al 2017). Important questions about the various approaches persist and include the appropriate type or level of diversity on which to focus (e.g., individual species, biotic communities, ecological systems, or geophysical settings),

45 the criteria by which areas should be selected, specific protocols for optimizing reserve selection, 
and the amount of protected area needed to achieve conservation goals. Over time, focus has shifted from isolated reserves to interconnected reserve networks selected based on landscape ecology principles (e.g., Soulé \& Terborgh 1999; Briers 2002; Cerdeira et al 2005; Beier 2012), and from single species to multi-species and, more recently, ecosystem- and geophysical-based

50 approaches that seek to conserve "nature's stage" (e.g., Hunter et al 1988; Noss 1996; Pickett et al. 1992; Anderson and Ferree 2010; Beier et al 2015; Wurtzebach and Schultz 2016). These approaches emphasize retaining representative ecological and/or geophysical settings instead of focal species, and as such provide a "coarse filter" (sensu Hunter et al 1988) for biodiversity conservation. The use of such a coarse filter is touted as being proactive for species conservation

55 because if ecological settings (which provide the habitat that species depend on) remain intact, most species will also be conserved (e.g., Scott et al. 1993). Moreover, it is assumed that if ecological settings remain intact, critical ecological and evolutionary processes, such as nutrient and sediment transport, interspecific interactions, dispersal, gene flow and disturbance regimes, will also be maintained and provide the necessary environmental stage for climate adaptation to

60 occur (Beier 2012; Beier et al 2015). This prospect is appealing because biological diversity (with shifting composition) could be conserved under changing environmental conditions with the same expenditure of funds and commitment of land to conservation and without specific and detailed knowledge of every species of interest.

While the general concept of focusing on nature's stage is both appealing and intuitive, there 65 are many different approaches for doing so. One approach has been to focus solely on the geophysical environment without attention to the biota, and identify and prioritize representative, diverse and connected geophysical settings based on one or more metrics (e.g., Anderson et al 2014; Beier et al 2015). Here the goal is to conserve the abiotic stage and allow the biota to 
change and "play out" on this stage over time, especially in response to climate change (Beier

70 and Brost 2010; Beier 2012). For example, Anderson et al (2014) measured site resiliency using a combination of two metrics: 1) landscape diversity, which refers to the number of microhabitats and climatic gradients available within a given area based on the variety of landforms, elevation range, soil diversity, and wetland extent and density, and 2) local connectedness, which refers to the accessibility of neighboring natural areas. This measure of

75 site resiliency is agnostic to the distribution of biota and explicit climate change projections, but is somewhat sensitive to the impacts of human development via the fragmentation of natural areas. This approach has been shown to perform well as a surrogate for species diversity (Anderson et al 2014).

An alternative approach, but not without its critics (e.g., Brown and Williams 2016), has been

80 to focus on ecosystems, with attention to both the biotic as well as geophysical environment, and use the concept of ecological integrity to identify and prioritize places of conservation value (e.g., Tierney et al 2009, Theobald 2013, Wurtzebach and Schultz 2016, Belote et al 2017). Here the goal is to conserve the "ecological stage" by focusing on places with high ecological integrity that can sustain the biota and critical ecological processes. Ecological integrity is broadly defined

85 as "the ability of an ecological system to support and maintain a community of organisms that has species composition, diversity, and functional organization comparable to those of natural habitats within a region; an ecological system has integrity when its dominant ecological characteristics (e.g., elements of composition, structure, function, and ecological processes) occur within their natural ranges of variation and can withstand and recover from most 90 perturbations imposed by natural environmental dynamics or human disruptions." (Parrish et al. 2003, p. 852). 
As part of a broader framework for biodiversity conservation in the northeastern United States that we developed initially under the auspices of the Conservation Assessment and Prioritization System (CAPS) project (www.umasscaps.org) and expanded for the Designing

95 Sustainable Landscapes (DSL) project in collaboration with the North Atlantic Landscape Conservation Cooperative (NALCC, McGarigal et al 2017), we developed an ecosystem-based, landscape ecological approach for quantitatively evaluating the relative ecological integrity, and thus the biodiversity conservation value of every raster cell over varying extents (e.g., watershed, ecoregion, state) across the Northeast. Our approach is based on a modified concept of ecological

100 integrity, which we define as the ability of an area to support native biodiversity and the ecosystem processes necessary to sustain that biodiversity over the long term. Importantly, our definition emphasizes the maintenance of ecological functions rather than the maintenance of a particular reference biotic composition and structure, and thus accommodates the modification or adaptation of systems (in terms of biotic composition and structure) over time to changing

105 environments (e.g., as driven by climate change) as in the geophysical approach. Moreover, our approach rests on an unproven and perhaps unprovable assumption that an index of ecological integrity can be measured that reflects the ecological functions necessary to confer ecological integrity to a site. Our approach assumes that by conserving relatively intact and resilient ecological settings as measured by an appropriate index, we can conserve most species and

110 ecological processes. Moreover, by identifying the lands and waters most worthy of protection based on the highest relative ecological integrity, conservation organizations can target their limited dollars strategically. In this paper, we describe our ecosystem-based assessment of ecological integrity, which is encapsulated into an index of ecological integrity (IEI), and illustrate its application for conservation in the northeastern US. 
Our approach is raster-based and can be applied at any spatial resolution over any landscape extent large enough to capture a sufficiently wide gradient of ecological settings and anthropogenic land use impacts. Here, we describe the method generically and demonstrate its application to a $30 \mathrm{~m}$ resolution raster over the extent of the 13 northeastern states (VA, WV,

120 DE, MD, PA, NJ, NY, CT, RI, MA, NH, VT, ME) plus Washington DC (hereafter the Northeast). All modeling was done with custom APL programs (APL+Win 12, APLNow, LLC). Source code can be obtained from B. Compton. Figure 1 depicts a schematic outline of the analytical process described in this section.

\section{Ecological settings and ecosystems}

125 Central to our approach is the characterization of the biophysical setting of every cell. For this purpose, we derive a comprehensive but parsimonious suite of continuous "ecological settings" variables that characterize important abiotic and anthropogenic aspects of the environment

(Table 1). Each settings variable is selected based on a distinct and well-documented influence on ecological systems. The only biotic attribute that we include is potential dominant life form

130 (e.g., grassland, shrubland, forest). Otherwise, the ecological settings are agnostic to vegetation composition and structure, as in the geophysical stage approach. The exact list of variables and their data source can vary among applications depending on data availability and objectives. The setting variables are used in the calculation of the individual ecological integrity metrics and (optionally) in the calculation of the composite IEI described below.

135 We also assign each cell to a discrete ecosystem type, which can be based on any classification scheme that can be mapped (e.g., Appendix B). Ecosystems are used as an 
organizational framework for scaling the ecological integrity metrics described below. It is not necessary to assume discrete ecological systems, since an ecological gradient approach for scaling the metrics is also feasible (see below), but for ease of interpretation and consistency

140 with other derived products, we have used discrete ecosystems in all of the conservation applications to date.

\section{Ecological neighborhoods}

Ecological neighborhoods (sensu Addicott et al 1987) play an important role in the computation of the ecological integrity metrics described below, as in other approaches (e.g., Theobold 2013,

145 Anderson et al 2014), but our particular implementation of neighborhoods are distinctive of our approach. We use non-linear kernels to specify how to weight the ecological neighborhood of a focal cell; i.e., to determine how much influence a neighboring cell has on the integrity of the focal cell. We use three different kinds of kernel estimators: 1) standard kernel estimator for the non-watershed-based metrics, 2) resistant kernel estimator for the connectedness metrics, and 3)

150 watershed kernel estimator for the watershed-based metrics.

Standard kernel—The standard kernel produces a three-dimensional surface representing an estimate of the underlying probability distribution (or ecological neighborhood) centered on a focal cell (Silverman 1986). The standard kernel estimator begins by placing a standard kernel (e.g., Gaussian kernel) over a focal cell. In the standard Gaussian kernel, the "bandwidth" which

155 controls the spread of the kernel is equal to one standard deviation and accounts for $39 \%$ of the kernel volume. The value of the kernel at each cell represents the weight of the cell, which decreases monotonically and nonlinearly from the focal cell according to the kernel function as the distance from the focal cell increases. Typically the kernel is scaled such that the weights sum to one across all cells. Lastly, the kernel weights are multiplied by the value of the 
160 ecological attribute under consideration (e.g., traffic intensity, nutrient loading, or percent impervious) and summed to produce a kernel-weighted average.

We can think of the standard kernel as an estimate of the ecological neighborhood of the focal cell, where the size and shape of the kernel represent how the strength of the ecological relationship varies (nonlinearly) with distance from the focal cell (Fig. 2a). The standard kernel

165 estimator provides an estimate of the intensity of an ecological attribute within that ecological neighborhood; i.e., the kernel-weighted mean of the attribute. We use the standard kernel estimator, at various bandwidths (reflecting the width of the kernel), to estimate the intensity of point features (e.g., point sources of pollution), linear features (e.g., roads), and patches (e.g., developed land cover), including all non-watershed-based ecological integrity metrics with the 170 exception of connectedness.

Resistant kernel.— Like a standard kernel the resistant kernel is used to assign weights to a neighborhood around a focal cell with the critical difference being that the higher weight is now assigned to cells that are easier to get to (smaller cost-distances) instead of simply closer in Euclidian distance. Introduced by Compton et al. (2007), the resistant kernel is a hybrid between

175 two existing approaches: the standard kernel estimator as described above and least-cost paths based on resistant surfaces. Resistant surfaces (also referred to as cost surfaces) are being increasingly used in landscape ecology to model ecological flows in heterogeneous landscapes (Zeller et al 2012). In a patch mosaic, for example, a resistance value (or cost) is assigned to each patch type, typically representing a divisor of the expected rate of ecological flow (e.g.,

180 dispersing or migrating animals) through a patch type. In a least-cost path approach, the cost distance (or functional distance) between two points along any particular pathway is equal to the cumulative cost of moving through the associated cells. This least-cost path approach can be 
extended to a multidirectional approach that measures the functional distance (or least-cost distance) from a focal cell to every other cell in the landscape as a means of defining the

185 accessible ecological neighborhood. These distances can then be converted to weights based on a Gaussian or other function such that higher weight is assigned to closer (in least-cost distance) cells.

In the resistant kernel algorithm, resistance values can be assigned any number of ways, but in this application we assign landscape resistance uniquely to each neighboring cell based on its

190 "ecological distance" to the neighboring cell, where ecological distance is derived from the suite of ecological settings variables. Because resistance of neighboring cells is based on ecological distance to the focal cell, landscape resistance varies dynamically across the landscape; i.e., there is a unique landscape resistance surface for each focal cell. For each focal cell, first we calculate the weighted Euclidean distance between the focal cell and each neighboring cell in settings

195 space (across all dimensions), where each settings variable is first range rescaled 0-1 and then multiplied by its assigned weight to reflect its importance in determining landscape resistance (Table 1), as follows:

$$
d_{n}=\sqrt{\sum_{i=1}^{p}\left(w_{i}\left(x_{f i}-x_{n i}\right)\right)^{2}}
$$

where $d_{n}=$ Euclidean distance between the $n^{\text {th }}$ neighboring cell and the focal cell; $i=1$ to $p$ settings variables (dimensions); $w_{i}=$ weight for the $i^{\text {th }}$ settings variable; $x_{i f}=$ value of the $i^{\text {th }}$

200 settings variable (scaled 0-1) at the focal cell; and $x_{n i}=$ value of the $i^{\text {th }}$ settings variable at the $n^{\text {th }}$ neighboring cell. Next, we divide the result above by the maximum possible weighted Euclidean distance based on the non-anthropogenic (a.k.a. "natural") settings variables. Thus, if the focal 
cell and neighboring cell are both undeveloped and have identical values across all natural settings variables, the weighted Euclidean distance will always equal zero. On the other hand, if

205 the two cells have maximally different values (i.e., a difference of one for each of the natural settings variables), the weighted Euclidean distance will always equal one. However, if the neighboring cell is developed, the weighted Euclidean distance can exceed one. Lastly, we convert weighted Euclidean distance to resistance by multiplying it by a constant and adding one to ensure that resistance is never less than one. The constant (which interacts with bandwidth)

210 determines the theoretical maximum resistance between two undeveloped cells (i.e., when their weighted Euclidean distance is one), which we set to be 50 for the connectedness metric and 300 for the aquatic connectedness metrics described below. We selected the constants based on preliminary analyses in which we subjectively evaluated the behavior of the metric in discriminating among undeveloped and developed settings. By setting anthropogenic weights to

215 be relatively high, the resistance (e.g., of a high-traffic expressway or a large dam) can become high enough to cause a neighboring developed cell to act as a complete barrier to spread in the resistant kernel. Consequently, rivers and other natural features can act as partial barriers to spread from focal cells with a high ecological distances (e.g., dry oak forests), but the maximum resistance between natural features is never more than two, while anthropogenic features such as 220 highways can have higher resistances up to the maximum value determined by the constant.

A detailed description of the resistant kernel algorithm is given in Appendix C. Briefly, using the resistant surface described above, the resistant kernel computes the least cost distance to each neighboring cell (i.e., cumulative cost of spreading from the focal cell to the neighboring cell along the least cost path) and transforms these distances into probabilities based on the

225 specified kernel, such that the probabilities (or weights) sum to one across all cells. The end 
result is a resistant kernel that depicts the functional ecological neighborhood of the focal cell (Fig. 2b). In essence, the standard kernel is an estimate of the fundamental ecological neighborhood and is appropriate when resistance to movement is minimal (e.g., highly vagile species), while the resistant kernel is an estimate of the realized ecological neighborhood when

230 resistance to movement is nontrivial. The resistant kernel can also be thought of as representing a process of spread (e.g., dispersal) to or from the focal cell that combines the cost of moving through a heterogeneous and resistant neighborhood with the typically nonlinear cost of moving any distance away from the focal cell. In our ecological integrity assessment, we use the resistant kernel estimator in the terrestrial and aquatic connectedness metrics.

235 Watershed kernel.-The standard kernel estimator may not be meaningful for aquatic communities where the ecological neighborhood is more likely to be the watershed area above the focal cell than a symmetrical area around the focal cell. Thus, for the watershed-based metrics, we use a watershed kernel estimator based on a time-of-flow model (Randhir et al. 2001) as described in detail in Appendix D. Briefly, the time-of-flow model estimates the time

$240(t)$ it takes for a drop of water (or water-born materials such as pollutants) to reach the focal cell; it ranges from zero at the focal cell to some upper bound based on the size and characteristics of the watershed. We rescale $t$ to range $0-1$ by dividing $t$ by the maximum observed value of $t$ for the watershed of the focal cell and then taking the complement. In the resulting kernel, the weight ranges from 1 (maximum influence) at the focal cell to 0 (no influence) at the cell with

245 the least influence (i.e., at the furthest edge of the watershed). In essence, kernel weights decrease monotonically as the distance upstream and upslope from the focal cell increases, but the weights decrease much faster across land than water so that the kernel typically extends much farther upstream than upslope. The resulting kernel can be viewed as a constrained 
watershed in which cells in the stream and closer to the focal cell have higher weight and cells in

250 the upland and farther from the stream, especially on flat slopes with forest cover, have increasingly less weight (Fig. 2c).

Clearly, this simple time-of-flow model does not capture all the nuances of real landscapes that influence the actual time it takes for water to travel from any point in the watershed to the focal cell (e.g., soil characteristics that influence infiltration of precipitation and vegetation

255 characteristics that influence water loss through evapotranspiration), but it nonetheless provides a much more meaningful way to weight the importance of neighboring cells than either the standard kernel estimator that does not account for flow or a uniform watershed kernel in which all cells in the watershed count equally.

\section{Ecological integrity metrics}

260 Our ecological integrity assessment involves computing a suite of metrics that characterize the ecological neighborhood of each focal cell based on one of the kernel estimators described above. Currently, our suite of metrics measure two important components of ecological integrity: intactness and resiliency.

Intactness refers to the freedom from human impairment (or anthropogenic stressors) and is

265 measured using a broad suite of individual stressor metrics (Table 2) such that the greater the level of anthropogenic stress, the lower the estimated intactness. The stressor metrics are computed for all undeveloped cells, although some metrics apply only to certain ecosystems (e.g., watershed-based metrics apply only to aquatic and wetland systems). Each stressor metric measures the magnitude of the anthropogenic stressor within the ecological neighborhood of

270 each cell and is uniquely scaled to the appropriate units for the metric. For example, the road 
traffic metric measures the intensity of road traffic (based on the estimated probability of an animal being hit by a vehicle while crossing a road given the estimated mean traffic rate) in the neighborhood surrounding the focal cell based on a standard logistic kernel (Fig. 3a). The value of each metric increases with increasing intensity of the stressor within the ecological

275 neighborhood of the focal cell. Thus, the raw value of a stressor metric is inversely related to intactness and thus ecological integrity. The value of the metric at any location is generally independent of the particular ecological setting or ecosystem of the focal cell, as it depends primarily on the magnitude of the stressor emanating outward from the anthropogenic features of interest (e.g., roads). Thus, the stressor metrics are all interpretable in their raw-scale form; i.e.,

280 they do not need to be rescaled by ecological setting or ecosystem (as described below) to be meaningfully interpreted.

Each metric measures a different anthropogenic stressor and is intended to reflect a unique and well-documented relationship between a human activity and an ecological function. However, these stressor metrics are not statistically independent, since the same human activity

285 can have multiple ecological effects. Consequently, these stressor metrics are viewed as a correlated set of metrics that collectively assess the impact of human activities on the intactness of the ecological setting or ecosystem.

Resiliency refers to the capacity to recover from disturbance and stress; more specifically, the amount of disturbance and stress a system can absorb and still remain within the same state or 290 domain of attraction, i.e., resist permanent change in the function of the system (Holling 1973, 1996). In other words, as reviewed by Gunderson (2000), resiliency generally deals with the capacity to maintain characteristic ecological functions in the face of disturbance and stress. In contrast to intactness, resiliency is both a function of the local ecological setting, since some 
settings are naturally more resilient to stressors (e.g., a wetland isolated by resistant landscape

295 features is less resilient to species loss than a well-connected wetland, because the latter has better opportunities for recolonization of constituent species), and the level of stress, since the greater the stress the less likely the system will be able to fully recover or maintain ecological functions. Moreover, the concept of resiliency applies to both the short-term or immediate capacity to recover from disturbance and the long-term capacity to sustain ecological functions

300 in the presence of stress. The landscape attributes that confer short-term resiliency may not be the same as those that confer long-term resiliency, as discussed later. Given these considerations, resiliency is a complex, multi-faceted concept that cannot easily be measured with any single metric. For the applications presented in this paper we implemented a few different resiliency metrics (Table 2).

305 Like the stressor metrics, the resiliency metrics are computed for all undeveloped cells. In contrast to the stressor metrics, the value of each resiliency metric increases with increasing resiliency, so larger values connote greater integrity. Also in contrast to the stressor metrics, the value of the resiliency metric at any location is dependent on the particular ecological setting of the focal cell and its neighborhood. For example, the connectedness metric measures the 310 functional connectivity of a focal cell to its ecological neighborhood (based on a resistant Gaussian kernel); more specifically, the capacity for organisms to move to and from the focal cell from neighboring cells with a similar ecological setting as the focal cell (Fig. 3b). Consequently, connectedness is especially relevant for less vagile organisms where the resistance of the intervening landscape limits movement to and from the focal cell. Connectedness confers 315 resiliency to a site since being connected to similar ecological settings should promote recovery of the constituent organisms following a local disturbance. 
In contrast to the stressor metrics, the resiliency metrics are not particularly useful in their raw-scale form because they do not have interpretable units. Instead, they are best interpreted when rescaled by ecological setting or ecosystem (see below) so that what constitutes high

320 resiliency for a small patch-forming ecological system such as a wetland need not be the same as for a matrix-forming system such as upland forest. Like the stressor metrics, each resiliency metric measures resiliency from a different perspective and is intended to reflect a unique and well-documented relationship between landscape context and ecological function, and resiliency metrics are correlated, yielding a set of metrics that collectively assess the capacity of a site to

325 recover from or adapt to disturbance and stress.

\section{Index of ecological integrity}

The individual stressor and resiliency metrics can be used by themselves, but it is more practical to combine them into a composite index (IEI) for conservation applications.

Quantile-rescaling. - Each of the raw stressor and resiliency metrics are scaled differently.

330 Some are bounded 0-1 while others have no upper bound. Moreover, each of the metrics will have a unique empirical distribution for any particular landscape. In order to meaningfully combine these metrics into a composite index, therefore, it is necessary to rescale the raw metrics to put them on equal ground. Quantile-rescaling involves transforming the raw metrics into quantiles, such that the poorest cell gets a 0.01 and the best cell gets a 1. Quantile-rescaling

335 facilitates the compositing of metrics by putting them all on the same scale with the same uniform distribution regardless of differences in raw units or distribution. Moreover, quantiles have an intuitive interpretation, because the quantile of a cell expresses the proportion of cells with a raw value less than or equal to the value of the focal cell. Thus, a 0.9 quantile is a cell that has a metric value that is greater than $90 \%$ of all the cells, and all the cells with $>0.9$ quantile 
340 values comprise the best $10 \%$ within the analysis area. In light of these advantages, it is importance to recognize that quantile scaling means the ecological difference between say 0.5 and 0.6 is not necessarily the same as the ecological difference between say 0.8 and 0.9 .

There are two fundamentally different ways to conduct quantile rescaling. In the first approach, which we refer to as "ecosystem-based rescaling," quantile-rescaling is done by

345 discrete ecosystems. Ecosystem-based rescaling means that forests are compared to forests, emergent marshes are compared to emergent marshes, and so on. It doesn't make sense to compare the integrity of an average forest cell to that of an average wetland cell, because wetlands have been substantially more impacted by human activities such as development than forests, and they are inherently less-connected to other wetlands. Rescaling by ecosystem means

350 that all the cells within an ecosystem are ranked against each other in order to determine the cells with the greatest relative integrity for each ecosystem. In the applications of IEI to date (see below) we have used this form of rescaling. In the second approach, which we refer to as "gradient-based rescaling," quantile-rescaling is done by comparing focal cells to similar cells based on multivariate distance in ecological setting space, which does not rely on discrete

355 ecosystems. Comparative performance of these two alternative rescaling approaches remains an important subject for future research.

Ecological integrity models. - The next step is to combine the quantile-rescaled metrics into the composite index. However, given the range of metrics (Table 2), it is reasonable to assume that some metrics are more relevant to some ecological settings or ecosystems than others. For

360 example, the watershed-based stressor metrics and aquatic connectedness were designed specifically for aquatic and/or wetland communities. Moreover, it is reasonable to assume that the weights applied to the metrics should vary among ecological settings or ecosystems, since 
what stressors matter most, for example, to an emergent marsh may not be the same as for an upland boreal forest. Consequently, we employ ecosystem-specific ecological integrity models to

365 weight the component metrics in the composite index (e.g., Appendix F). An ecological integrity model is simply a weighted (by expert teams, Appendix F) linear combination of metrics designated for each ecosystem, although for parsimony sake we generally designate a unique model for each ecological formation, which is a group of similar ecosystems (Appendix B).

370 Rescaling the final index.-Lastly, we quantile-rescale the final composite index by ecosystem again to ensure the proper quantile interpretation. The final result is a raster that ranges 0 -1. It is important to recognize that quantile-rescaling means that the results are dependent on the extent of the analysis area, because the quantiles rank cells relative to other cells within the analysis area (Fig. 4). The best of the Kennebec River watershed, for example, is 375 not the same as the best of the state of Maine or the entire Northeast. Of course, dependence on landscape extent is true of any algorithm that compares a site to all other sites. Consequently, quantile-rescaling is done separately for each analysis unit of interest. Ultimately, the choice of extent for the analysis units is determined by the application objectives, but with consideration of the mapped heterogeneity. For example, our experience has shown us that when using the DSL

380 ecosystem map, scaling by ecosystems at extents less than roughly a HUC6-level watershed can produce spurious results owing to the categorical mapping of ecosystems and the limited extent of some ecosystems. HUCs are a USGS system for hierarchically classifying nested watersheds, such that a HUC6-level watershed is comprised of two or more HUC8-level sub-watersheds.

Interpreting IEI.- It is critical to recognize the relative nature of IEI; a value of 1 does not 385 mean that a site has the maximum absolute ecological integrity (i.e., completely unaltered by 
human activity and perfectly resilient), only that it is the best of that ecological setting or ecosystem within the geographic extent of that particular analysis unit. In an absolute sense, the best within any particular geographic extent may still be degraded. Consequently, IEI is only useful as a comparative assessment tool. In addition, the final IEI has a nicely intuitive

390 interpretation because the quantile of a cell expresses the proportion of cells with a raw value less than or equal to the value of the focal cell, thus a cell with an IEI of 0.9 is among the best $10 \%$ in its ecosystem within its geographic extent.

\section{Index of Ecological Impact}

IEI characterizes the integrity of sites relative to other sites in a similar ecological setting or

395 ecosystem. Thus, it is a static measure of ecological integrity based on a snapshot of the landscape. It can be equally useful to assess the change in ecological integrity over time under a specific landscape change scenario (see Model Application). For this purpose, we developed the index of ecological impact (ecoImpact) to measure the change in IEI between the current and future timesteps relative to the current IEI; i.e., effectively delta IEI times current IEI. A site that

400 experiences a major loss of IEI has a high predicted ecological impact; i.e., a loss of say 0.5 IEI units reflects a greater relative impact than a loss of 0.2 units. Moreover, the loss of 0.2 units from a site that has a current IEI of 0.9 is more consequential than the same absolute loss from a site that has a current IEI of 0.5. Thus, ecoImpact reflects not only the magnitude of IEI loss, but also where it matters most—-sites with high initial integrity.

405 Delta-rescaling. - The derivation of ecoImpact consists of rescaling the individual raw metrics, but using a different rescaling procedure than we used with IEI, which suffers from what we call the "Bill Gates" effect when used for scenario comparison. This occurs when the value of the raw metric is decreased at a high-valued site without changing the quantile. This is analogous 
to taking 10 billion dollars away from Bill Gates, yet he remains among the richest $0.1 \%$ of

410 people in the world. Likewise, a small absolute change in a raw metric can, under certain circumstances, result in a large change in its quantile, even though the ecological difference is trivial. Therefore, the use of quantile-rescaling is not appropriate if we want to be sensitive to the absolute change in the integrity metrics. To address these issues, we developed delta-rescaling as an alternative to quantile-rescaling that is more meaningful when comparing landscapes.

415 Delta-rescaling is rather complicated in detail and thus is presented in full in Appendix G. Briefly, delta-rescaling involves computing the difference in the raw metric from its initial or baseline value rather than comparing it to the condition of ecologically similar cells or cells of the same ecosystem. These delta values are rescaled and combined in a weighted linear combination (as in IEI) and multiplied by the initial or baseline IEI to derive the final index (Fig.

420 5). The end result is that a cell with maximum initial $I E I$ (1) that is completely degraded $(1 \rightarrow 0)$ gets a value of -1 , indicating the maximum possible ecological impact. Conversely, a cell that experiences no change in IEI gets a value of 0 , indicating no ecological impact.

It is important to recognize the differences between ecoImpact and IEI. The former measures the change in IEI relative to the initial or baseline condition. Roughly speaking, ecoImpact

425 compares each cell to itself — the change in integrity over time — whereas IEI compares each cell to other cells of the same ecological setting or ecosystem within the specified geographic extent. Also, ecoImpact is weighted by the current IEI of the cell, so that impact is greatest where it matters most — cells with high initial IEI that lose most or all of their value. Even though the units of ecoImpact do not have an intuitive interpretation, the absolute value of the index is 430 meaningful for comparative purposes, and thus it can be summed across all cells in the landscape 
(or within a user-defined mask) to provide a useful numerical summary of the total ecological impact of alternative landscape change scenarios.

\section{Model Application}

To demonstrate the application of ecoImpact, we quantified the loss of ecological integrity 435 between 2010-2080 within the northeastern United States under two landscape change scenarios: (a) urban growth without additional land protection, and (b) same amount of urban growth but with strategic land protection based on a regional landscape conservation design (see www.naturesnetwork.org). For the first scenario only the existing secured lands representing $\sim 18 \%$ of the landscape (and lands otherwise unsuitable for development) were restricted from

440 future development. For the second scenario, 25\% of the highest ecologically-valued lands and waters as well as any lands already secured (representing a total of $\sim 34 \%$ of the landscape) or otherwise unsuitable for development, were protected from future development. For both scenarios, we simulated urban growth using the SPRAWL model that we developed in connection with the DSL project mentioned previously (McGarigal et al In review). The

445 SPRAWL model allocates forecasted demand for new development within subregions (representing counties or census block statistical areas) to local application panes (5 km on a side in our application) based on their landscape context using a unique matching algorithm, such that the more historical development that occurred in the matched training windows (i.e., in a similar landscape context) the higher proportion of the future demand is assigned to the application

450 pane. Subsequently, the demand in each pane is allocated among transition types (i.e., development classes) and then stochastically allocated to individual cells and patches based on suitability surfaces derived from logistic regression models unique to that landscape context. We conducted three replicate 70-year simulations of urban growth under each scenario and computed 
the average total impact (sum of ecoImpact across all cells) for each scenario. The total

455 ecological impact was 8.5\% less under the landscape conservation design scenario (Fig. 5). Consequently, even though the conservation design scenario restricted development from an additional $16 \%$ of the highest-valued locations, the reduced impact was only half that amount because there was still an abundance of moderate- to highly-valued lands that remained unprotected that suffered impacts from development.

\section{Discussion}

Coarse-filter ecological assessments are increasingly used by conservation organizations to evaluate ecological impacts and guide conservation planning, although there appears to be no consensus yet on a preferred approach (e.g., Andreasen et al 2001, Parrish et al 2003 , Tierney et al 2009, Beier et al 2015). We developed an approach that has been used in several real-world

465 applications (see below) that is distinctive in several ways.

First, our approach is based predominantly on geophysical settings (i.e., the geophysical stage) similar to approaches proposed by others (e.g., Anderson and Ferree 2010, Anderson et al 2014, Beier et al 2015), but modified to make limited use of the dominant biotic community as well. Specifically, we include the dominant potential life form of the vegetation in the broad

470 suite of ecological settings variables that are used to define the biophysical setting of each cell, which affects ecological similarity and resistance as incorporated into a few of the ecological integrity metrics. In addition, we use mapped ecosystems to assign models (i.e., weights) for combining the individual integrity metrics into the composite IEI and ecoImpact indices, which has at least three advantages. First, it allows the results of the analysis to be easily combined with

475 other products that adopt the same ecosystem classification. Second, it explicitly recognizes that ecological systems, which represent the co-dependency of the dominant biota and abiotic 
environment, are often a conservation target of interest, even while allowing the individual plant and animal species to vary among sites and over time. Lastly, it allows us to customize vulnerability to anthropogenic stressors among ecosystems, which can be incorporated directly

480 into the metric weights that form the integrity models. Note, if distinct ecosystems are not deemed meaningful or reliably mapped, we have an alternative gradient-based approach that can be used.

Second, our approach embraces the concept of ecological integrity, but defined in a manner that makes it less subject to the criticisms often leveled against the use of ecological integrity 485 (Brown and Williams 2016). In particular, our approach does not require the establishment of a reference condition or natural range of variation for each of the metrics as is customary for definitions of ecological integrity (Parrish et al 2003), which we purport is exceedingly difficult or even impossible to do in most applications. Instead, we compare each cell to other cells in a similar ecological setting or ecosystem, or each cell to itself at a different point in time, to derive 490 an index of relative integrity. Thus, our approach seeks to find the "best" places that are available today or that are likely to be impacted the least (or most depending on the application). In addition, while most approaches based on ecological integrity are heavily vegetation-centric in the constituent metrics (e.g., Wurtzebach and Schultz 2016), our approach relies very little on mapped vegetation patches and instead focuses on the anthropogenic stressors themselves (acting

495 somewhat independently of the mapped vegetation) in the individual metrics. For example, in contrast to most approaches our approach is agnostic to the current vegetation structural stage on a site, which we view as a dynamic property of the ecosystem (at least within the bounds of the dominant life form of the vegetation) and thus not germane to the integrity of the site. 
Third, our approach allows us to easily scale the results based on any geographic extent to 500 facilitate assessments and conservation planning at multiple scales. For example, IEI can be quantile-scaled within watersheds to inform local watershed-based conservation planning, or within states to inform state agencies with conservation responsibilities, or at even broader scales to inform regional conservation organizations such as federal agencies and regional land trusts (Fig. 6).

505 Fourth, our approach uses a variety of sophisticated kernel estimators to provide an effective assessment of the ecological neighborhood affecting the ecological integrity of a cell (Fig. 2). The use of ecological neighborhoods is not unique to our approach; for example, Theobold (2013) used standard kernel density estimators to develop an index of ecological integrity at the $90 \mathrm{~m}$ resolution for the entire United States. All of our kernel estimators reflect nonlinear

510 decreasing ecological influence as distance increases, which is one of the first principles of landscape ecology (Turner et and Gardner 2015). For example, our watershed-based metrics which evaluate the integrity of aquatic systems use a watershed kernel that honors how terrain and land cover affect the movement of water and water-born pollutants to a site, which is clearly more appropriate than treating all locations in the watershed the same. Similarly, our

515 connectedness metric uses a resistant kernel (Compton et al 2007) to represent how organisms and ecological processes move across the landscape in response to environmental resistance (Zeller et al 2012). We are unaware of other approaches that adopt these specific kinds of kernel estimators to evaluate ecological integrity, although our traversability metric (which is a version of connectedness), is used as a component of The Nature Conservancy's (TNC) terrestrial 520 resilience (Anderson and Ferree 2010). 
Limitations. - No approach is without limitations and ours is no exception. Among the many known limitations, a few are worth noting here. First, like all approaches, our suite of metrics is incomplete. There are anthropogenic stressors that we recognize as important but have not yet included due to the lack of reliable and regionally consistent high-resolution data (e.g., toxic 525 pollutants, hydrological disruptions), and other metrics that adopt an especially crude estimate of the stressor for the same reasons (e.g., non-native invasive plants based solely on land cover within the ecological neighborhood rather than explicit models of occurrence for each of the important organisms). Of course, these metrics can be added and/or improved as data and knowledge become available.

530 Second, while our approach relies on objective measures of intactness and resiliency, it still has an important subjective component that can be considered either a strength or weakness (Beazley et al 2010). Specifically, there are a number of model parameters that must be specified in order to compute the various ecological integrity metrics, including kernel bandwidths, weights for the ecological settings variables used in the resiliency metrics, and weights for the 535 metrics used in the ecosystem-specific ecological integrity models to create IEI and ecoImpact. At present these model parameters are assigned by experts in the context of a specific application, as there is no easy or meaningful way to empirically derive these parameters. While this allows the assessment to be customized to each application, it comes at the cost of having to defend the chosen set of model parameters.

540 Third, our current measurement of resiliency is based on two metrics, similarity and connectedness (and its aquatic counterpart), which reflects a limited perspective on resiliency. In particular, what may confer short-term resiliency as measured by our two metrics may be antagonistic to what may confer long-term resiliency in the face of rapid environmental (e.g., 
climate) change. For example, short-term resiliency of a site may be a function of the amount

545 and accessibility of similar environments in the neighborhood of the focal cell, since having larger and more connected local populations should facilitate population recovery of the constituent organisms (and thus ecosystem functions) following disturbance-which is the premise of our two resiliency metrics. However, long-term resiliency of a site may also be a function of the amount and accessibility of diverse environments in the neighborhood of the

550 focal cell, since having a diverse assemblage of environments nearby increases the opportunities for different organisms to fill the ecological niche space as the environment (e.g., climate) changes over time- which is the premise of the metrics used in the geophysical stage approach proposed by others (e.g., Anderson and Ferree 2010; Beier and Brost 2010; Beier 2012; Beier et al 2015). Consequently, while still unclear, it is possible that the factors driving short-term

555 resiliency may differ from those driving long-term resiliency in the face of environmental change. Note, to account for this possibility, in the landscape conservation design applications referenced below we combined IEI with TNC's terrestrial resilience metric (Anderson and Ferree 2010), which prioritizes sites based on local geophysical diversity and connectivity, to establish priorities for conservation core areas.

560 Lastly, despite their increasing use, measures of ecological integrity are exceedingly difficult if not impossible to validate (but see McGarigal et al. 2013, which provides a partial validation of IEI based on extensive field data on a number of taxa) given the long-term nature of the predictions, which has been a major source of criticism (Brown and Williams 2016). We sought to reduce the need for formal validation of IEI by eliminating the need for a reference condition 565 or natural range of variability and instead using quantile scaling to rate sites relative to each other. Indeed, IEI makes no assumptions about the absolute integrity of site, only that it is 
relatively more or less integral than another site. In this regard, each of the constituent metrics was chosen because of its clear and well-documented relationship with ecological functions that confer integrity to a site. For example, it is undisputed that increasing the intensity of roads and

570 road traffic near a site will adversely affect critical ecological processes such as organism dispersal, watershed hydrology, and sedimentation of streams (Forman et al 2003). IEI relies heavily on this well-established relationship between anthropogenic stressors and ecological integrity. Although the exact form and magnitude of the relationship is unknown; it may suffice to know that the relationship is monotonic.

575 Conservation applications.-Our coarse-filter ecological integrity assessment has been applied to a wide variety of real-world conservation problems. Detailed information about each of these applications can be found at the DSL project website (McGarigal et al 2017, www.umass.edu/landeco/research/dsl/dsl.html) or the UMassCAPS website (www.umasscaps.org).

580 - Critical Linkages.-Working in partnership with the North Atlantic Aquatic Connectivity Collaborative (NAACC), we have used IEI and the aquatic connectedness metric to evaluate and prioritize dam removals and road-stream crossing (culvert) upgrades in the Northeast for their potential to restore aquatic connectivity.

- Wetlands Assessment, Monitoring and Regulation.-Working in partnership with the MA 585 Department of Environmental Protection (DEP), MA Office of Coastal Zone Management, and U.S. EPA, we have used IEI in a variety of contexts to develop cost-effective tools and techniques for assessment and monitoring of wetland and aquatic ecosystems in Massachusetts, including the development and validation of indices of biotic integrity for selected wetland and aquatic systems. In addition, IEI is being used by DEP in permitting 
activities affecting wetlands pursuant to the MA Wetlands Protection Act; specifically, projects occurring in the top $40 \%$ of wetlands based on IEI are subject to additional DEP review.

- BioMap 2.-Working in partnership with the MA Department of Fish \& Game’s Natural Heritage \& Endangered Species Program and TNC’s Massachusetts Program, we used IEI 595 in the development of BioMap2 which serves as a guide for conservation decision making to preserve and restore biodiversity in Massachusetts; specifically, we used IEI to assist in the identification of forest cores, wetland cores, clusters of vernal pools and undeveloped landscape blocks with the highest potential for maintaining ecological integrity over time.

- Losing Ground.-Working in partnership with Mass Audubon to prepare the $4^{\text {th }}$ edition of 600 the Losing Ground publications (DeNormandie and Corcoran 2009), we used IEI and ecoImpact to assess the change in ecological integrity between 1971-2005 in Massachusetts; specifically, to quantify the indirect impacts of development beyond its direct footprint.

- South Coast Rail Project.-We used IEI and ecoImpact to assess the potential loss in 605 ecological integrity of several alternative routes for the proposed South Coast Rail system in southeastern Massachusetts.

- Connect the Connecticut and Nature's Network.-Working with a large partnership of organizations under the auspices of the North Atlantic Landscape Conservation Cooperative (NALCC), we used IEI in combination with several other data products to 610 identify and prioritize a set of terrestrial and aquatic "core areas" as part of a landscape conservation design for the Connecticut River watershed (Connect the Connecticut, 
www.connecttheconnecticut.org) and for the entire Northeast (Nature's Network, www.naturesnetwork.org).

Conclusions.-We suggest that the maintenance of ecological integrity is arguably the ultimate

615 goal of ecological conservation. However, given the complexity of the ecological integrity concept (Gunderson 2000), the measurement of ecological integrity has remained a daunting challenge for scientists and conservation practitioners. We presented an index of ecological integrity (IEI) to evaluate the relative integrity among sites of the same or similar ecosystem that is derived from readily available spatial data on land use and land cover and that can be applied

620 at any spatial resolution over any spatial extent (contingent upon data availability), and a corresponding index of ecological impact (ecoImpact) to assess changes in integrity over time. These two multi-metric indices emphasize the potential intactness (i.e., freedom from anthropogenic stressors) and resiliency (based on the ecological similarity and connectedness of the ecological neighborhood) of a site and make use of sophisticated kernels to represent

625 meaningful ecological neighborhoods for each of the constituent metrics. While not without acknowledged limitations, these metrics have proven useful in several real-world conservation applications.

\section{Acknowledgements}

This work was supported by the United States Fish and Wildlife Service, North Atlantic

630 Landscape Conservation Cooperative (NALCC), US Geological Survey Northeast Climate Science Center, Massachusetts Executive Office of Environmental Affairs, The Trustees of Reservations, Massachusetts Department of Environmental Protection, The Nature Conservancy, US Department of Transportation, and the University of Massachusetts, Amherst. We especially 
thank Andrew Milliken and Scott Schwenk of the NALCC for their continued support and close 635 involvement in several conservation applications involving the DSL project and the use of IEI. 
Table 1. Weights (determined by expert teams) assigned to ecological settings variables (see Appendix A for links to detailed descriptions of each variable) in the ecological integrity assessment. Resistance represents the weights assigned to the settings variables to determine

640 resistance between the focal cell and each neighboring cell in the resistant kernels and watershed kernels used in the Connectedness and Aquatic connectedness metrics, respectively. Distance represents the weights to determine ecological distance between the focal cell and each neighboring cell for Similarity, Connectedness, and Aquatic Connectedness metrics. The settings variables are arbitrarily grouped into broad classes for organizational purposes.

\begin{tabular}{|c|c|c|}
\hline & Resistance & Distance \\
\hline \multicolumn{3}{|l|}{ Energy } \\
\hline Incident solar radiation & 0.1 & 1 \\
\hline Growing season degree-days & 0.3 & 1 \\
\hline Minimum winter temperature & 0.1 & 1 \\
\hline Heat Index 35 & 0.1 & 1 \\
\hline Stream temperature & 0.1 & 1 \\
\hline \multicolumn{3}{|l|}{ Chemical \& physical substrate } \\
\hline Water salinity & 4 & 3 \\
\hline Substrate mobility & 2 & 2 \\
\hline CaCO3 content & 0.1 & 1 \\
\hline Soil available water supply & 0.05 & 0.5 \\
\hline Soil depth & 0.05 & 0.5 \\
\hline Soil pH & 0.05 & 0.5 \\
\hline \multicolumn{3}{|l|}{ Physical disturbance } \\
\hline Wind exposure & 0.1 & 1 \\
\hline Slope & 1 & 1 \\
\hline
\end{tabular}




\section{Resistance Distance}

Moisture \& hydrology

Wetness

4

8

Flow gradient

12

Flow volume

$5 \quad 5$

Tidal regime

Vegetation

Dominant life form

Development

Developed $^{1}$

Hard development ${ }^{1}$

1

1000

Traffic $^{1}$

2

40

0

Impervious $^{1}$

50

Terrestrial barriers $^{1}$

150

Aquatic barriers $^{2}$

100

0

645 1Setting variable not used in Aquatic Connectedness.

${ }^{2}$ Setting variable used only for Resistance in Aquatic Connectedness. 
Table 2. Intactness (a.k.a. stressor) and resiliency metrics included in the ecological integrity assessment for the northeastern United States (see Appendix E for links to detailed descriptions

650 of each metric). Note, the final suite of metrics can vary among applications depending on available data. For example, several additional coastal metrics have been developed for the state of Massachusetts, including salt marsh ditching, coastal structures, beach pedestrians, beach ORVs, and boating intensity. The metrics are arbitrarily grouped into broad classes for organizational purposes.

\begin{tabular}{|c|c|c|}
\hline Metric group & Metric name & Description \\
\hline \multirow{14}{*}{$\begin{array}{l}\text { Development } \\
\text { and Roads }\end{array}$} & Habitat loss & Intensity of habitat loss caused by all forms of \\
\hline & & development in the neighborhood surrounding the focal \\
\hline & & cell based on a standard Logistic kernel. \\
\hline & Watershed habitat & Intensity of habitat loss caused by all forms of \\
\hline & loss & development in the watershed above the focal cell based \\
\hline & & on a watershed kernel. \\
\hline & Road traffic & Intensity of road traffic (based on measured road traffic \\
\hline & & rates transformed into an estimated probability of an \\
\hline & & animal being hit by a vehicle while crossing the road given \\
\hline & & the mean traffic rate) in the neighborhood surrounding the \\
\hline & & focal cell based on a standard Logistic kernel. \\
\hline & Mowing \& & Intensity of agriculture (as a surrogate for mowing/plowing \\
\hline & plowing & rates) in the neighborhood surrounding the focal cell based \\
\hline & & on a standard Logistic kernel. \\
\hline
\end{tabular}




\begin{tabular}{|c|c|c|}
\hline Metric group & Metric name & Description \\
\hline & Microclimate & Magnitude of adverse induced (human-created) edge \\
\hline & alterations & effects on the microclimate integrity of patch interiors. \\
\hline \multirow[t]{11}{*}{ Pollution } & Watershed road & Intensity of road salt application in the watershed above an \\
\hline & salt & aquatic focal cell based on road class (as a surrogate for \\
\hline & & road salt application rates) and a watershed kernel. \\
\hline & Watershed road & Intensity of sediment production in the watershed above an \\
\hline & sediment & aquatic focal cell based on road class (as a surrogate for \\
\hline & & road sediment production rates) and a watershed kernel. \\
\hline & Watershed & Intensity of nutrient loading from non-point sources in the \\
\hline & nutrient & watershed above an aquatic focal cell based on land use \\
\hline & enrichment & class (primarily agriculture and residential land uses \\
\hline & & associated with fertilizer use, as a surrogate for nutrient \\
\hline & & loading rate) and a watershed kernel. \\
\hline Biotic & Domestic & Intensity of development associated with sources of \\
\hline \multirow[t]{7}{*}{ Alterations } & predators & domestic predators (e.g., cats) in the neighborhood \\
\hline & & surrounding the focal cell weighted by development class \\
\hline & & (as a surrogate for domestic predator abundance) and a \\
\hline & & standard Logistic kernel. \\
\hline & Edge predators & Intensity of development associated with sources of edge \\
\hline & & mesopredators (e.g., raccoons, skunks, corvids, cowbirds; \\
\hline & & i.e., human commensals) in the neighborhood surrounding \\
\hline
\end{tabular}




\begin{tabular}{|c|c|c|}
\hline Metric group & Metric name & Description \\
\hline & & $\begin{array}{l}\text { the focal cell weighted by development class (as a } \\
\text { surrogate for edge predator abundance) and a standard } \\
\text { Logistic kernel. }\end{array}$ \\
\hline & $\begin{array}{l}\text { Non-native } \\
\text { invasive plants }\end{array}$ & $\begin{array}{l}\text { Intensity of development associated with sources of non- } \\
\text { native invasive plants in the neighborhood surrounding the } \\
\text { focal cell weighted by development class (as a surrogate } \\
\text { for non-native invasive plant abundance) and a standard } \\
\text { Logistic kernel. }\end{array}$ \\
\hline & $\begin{array}{l}\text { Non-native } \\
\text { invasive } \\
\text { earthworms }\end{array}$ & $\begin{array}{l}\text { Intensity of development associated with sources of non- } \\
\text { native invasive earthworms in the neighborhood } \\
\text { surrounding the focal cell weighted by development class } \\
\text { (as a surrogate for non-native invasive earthworm } \\
\text { abundance) and a standard Logistic kernel. }\end{array}$ \\
\hline Climate & Climate stress & $\begin{array}{l}\text { Magnitude of climate change stress at the focal cell based } \\
\text { on the climate niche of the corresponding ecological } \\
\text { system and the predicted change in climate between 2010- } \\
2080 \text { (i.e., how much is the climate of the focal cell } \\
\text { moving away from the climate niche envelope of the } \\
\text { corresponding ecological system). }\end{array}$ \\
\hline Hydrologic & Watershed & Intensity of impervious surface (as a surrogate for \\
\hline Alterations & imperviousness & hydrological alteration) in the watershed above an aquatic \\
\hline
\end{tabular}




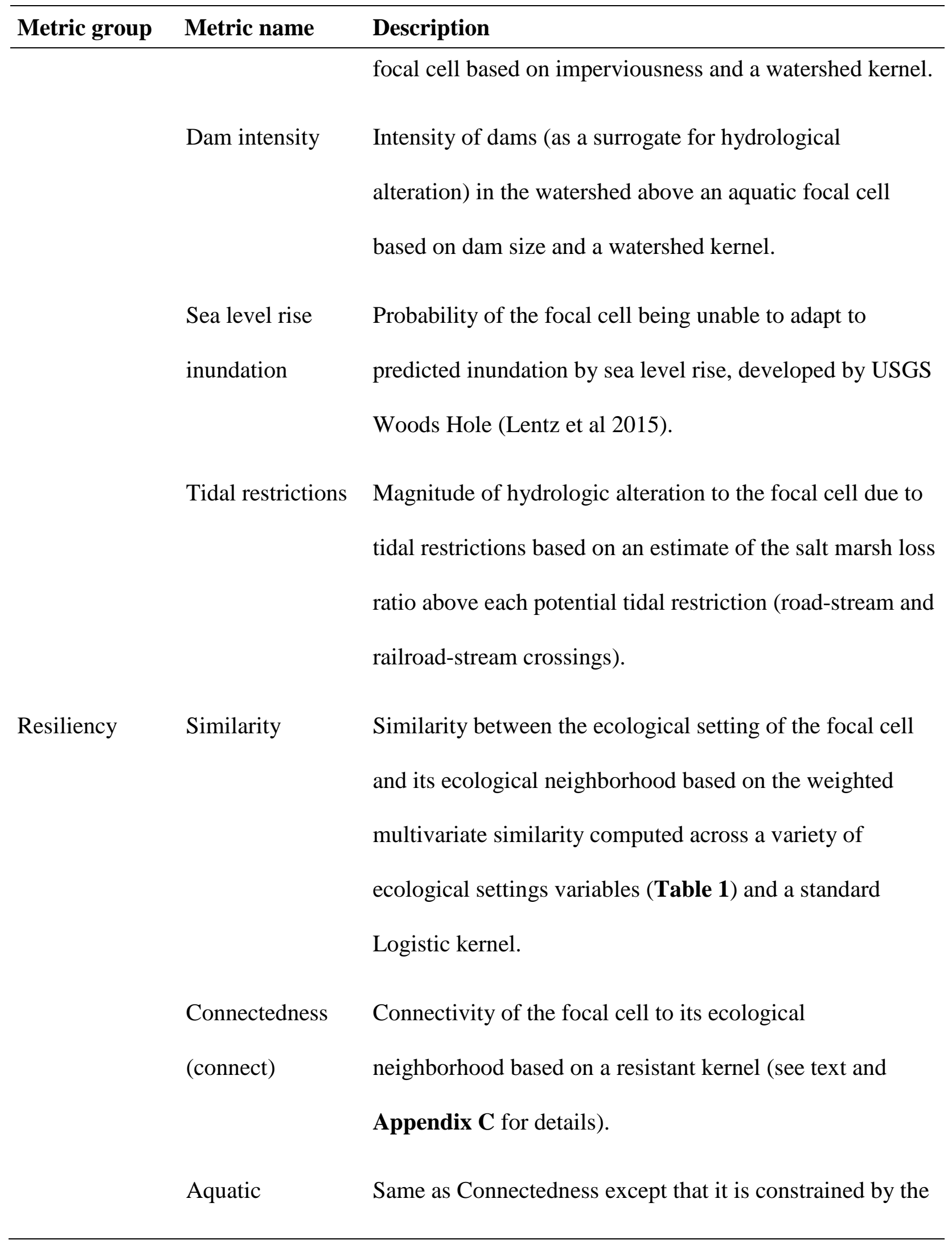




\section{Metric group Metric name Description}

connectedness extent of aquatic ecosystems, such that the connectivity

being assessed pertains to flows and disruption of flows

(e.g., culverts and dams) within the aquatic network. 
Figure 1. Schematic outline of the workflow associated with deriving the index of ecological integrity (IEI) and the index of ecological impact (ecoImpact) as described in the text.

Figure 2. Kernel estimators to estimate the ecological neighborhood of a focal cell (indicated by

660 the red cross for each kernel) in an area west of Albany, New York: (a) standard Gaussian kernel around a focal cell in which the weight of the kernel at any cell is indicated by the color gradient and reflects the bandwidth (spread) of the kernel; (b) resistant Gaussian kernel around a focal cell in which the weight of the kernel at any cell is indicated by the color gradient and reflects bandwidth (spread) of the kernel as well as the resistance of the intervening landscape; and (c)

665 watershed kernel in which the estimated relative time-of-flow from any cell within the watershed of the focal cell to the focal cell is indicated by the color gradient. Image is portrayed with hillshading.

Figure 3. (a) traffic (stressor) metric and (b) connectedness (resiliency) metric (scaled for the northeastern United States) for the North Quabbin region of western Massachusetts. See Table 2

670 for a brief description and Appendix E for a detail description of these two metrics. Note, the color legend is reversed in these two metrics so that the blue end of the gradient represents sites with greater ecological integrity (i.e., less traffic and greater connectedness in this case). Images are portrayed with hillshading.

Figure 4. Index of ecological integrity (IEI) scaled by (a) the entire northeastern United States

675 and (b) by HUC6-level watersheds for an area northwest of State College, Pennsylvania. See the text for a description of IEI and Table 2 and Appendix E for descriptions of the constituent metrics. Larger values represent greater ecological integrity. Images are portrayed with hillshading. 
Figure 5. Index of ecological impact (ecoImpact) representing the loss of ecological integrity

680 between 2010-2080 under two landscape change scenarios: (a) urban growth without additional land protection, and (b) same amount of urban growth but with strategic land protection (delineated polygons) based on a regional landscape conservation design (see www.naturesnetwork.org), for an area west of Manchester, New Hampshire. ecoImpact ranges from 0 (no impact) to -1 (maximum impact). The total impact (sum of ecoImpact across all cells, 685 averaged across three stochastic simulation runs under each scenario) was 8.5\% less under the landscape conservation design scenario. Note, the details of these two landscape change scenarios are not relevant to the demonstration of ecoImpact and thus have been omitted here. Images are portrayed with hillshading.

Figure 6. Index of ecological integrity (IEI) scaled by the entire northeastern United States (a;

690 larger values represent greater ecological integrity) and the corresponding Index of ecological impact (ecoImpact) representing the loss of ecological integrity between 2010-2080 under a baseline urban growth scenario without additional land protection (b, larger negative values represent greater ecological impact). 
695 Figure 1

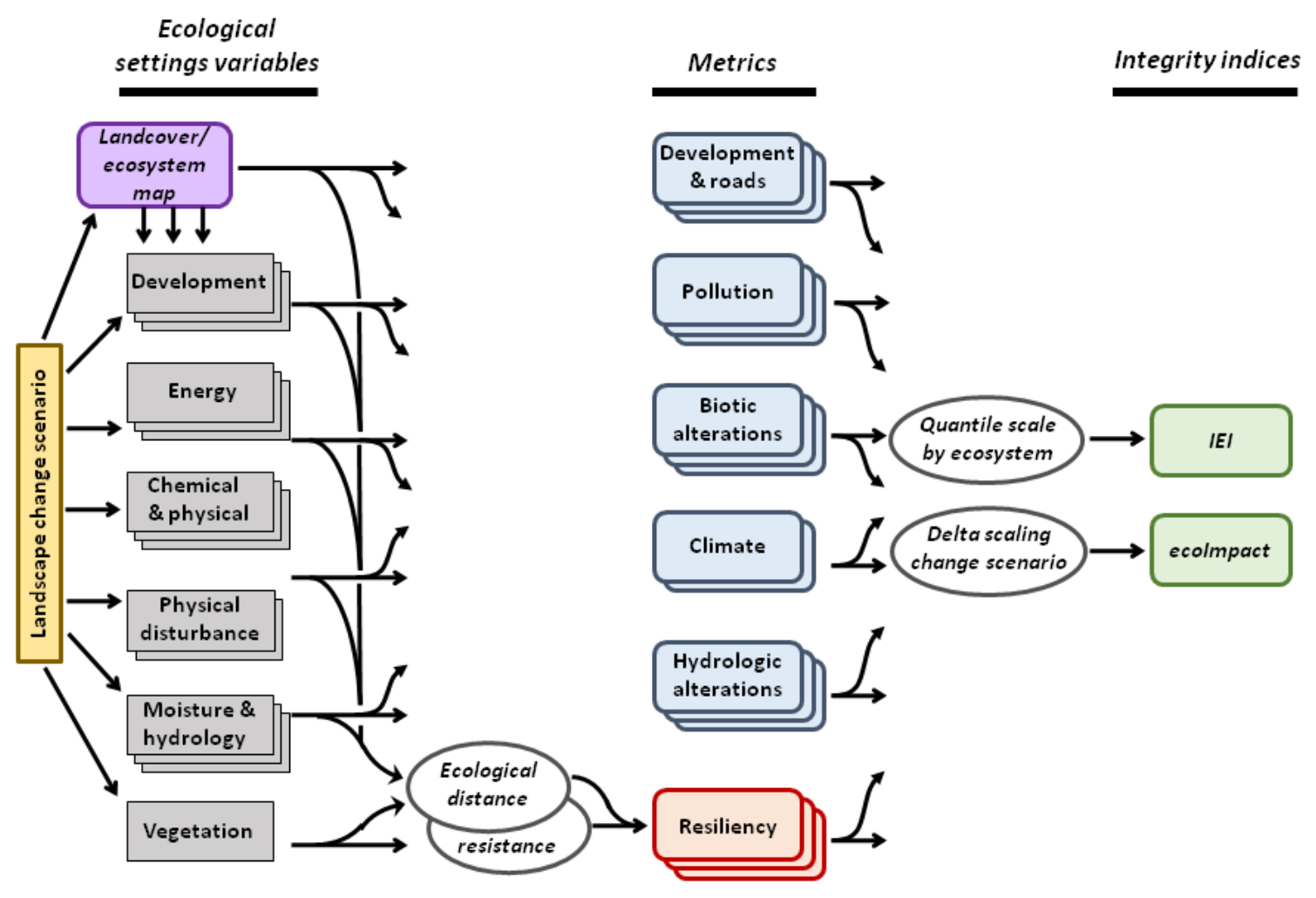


Figure 2

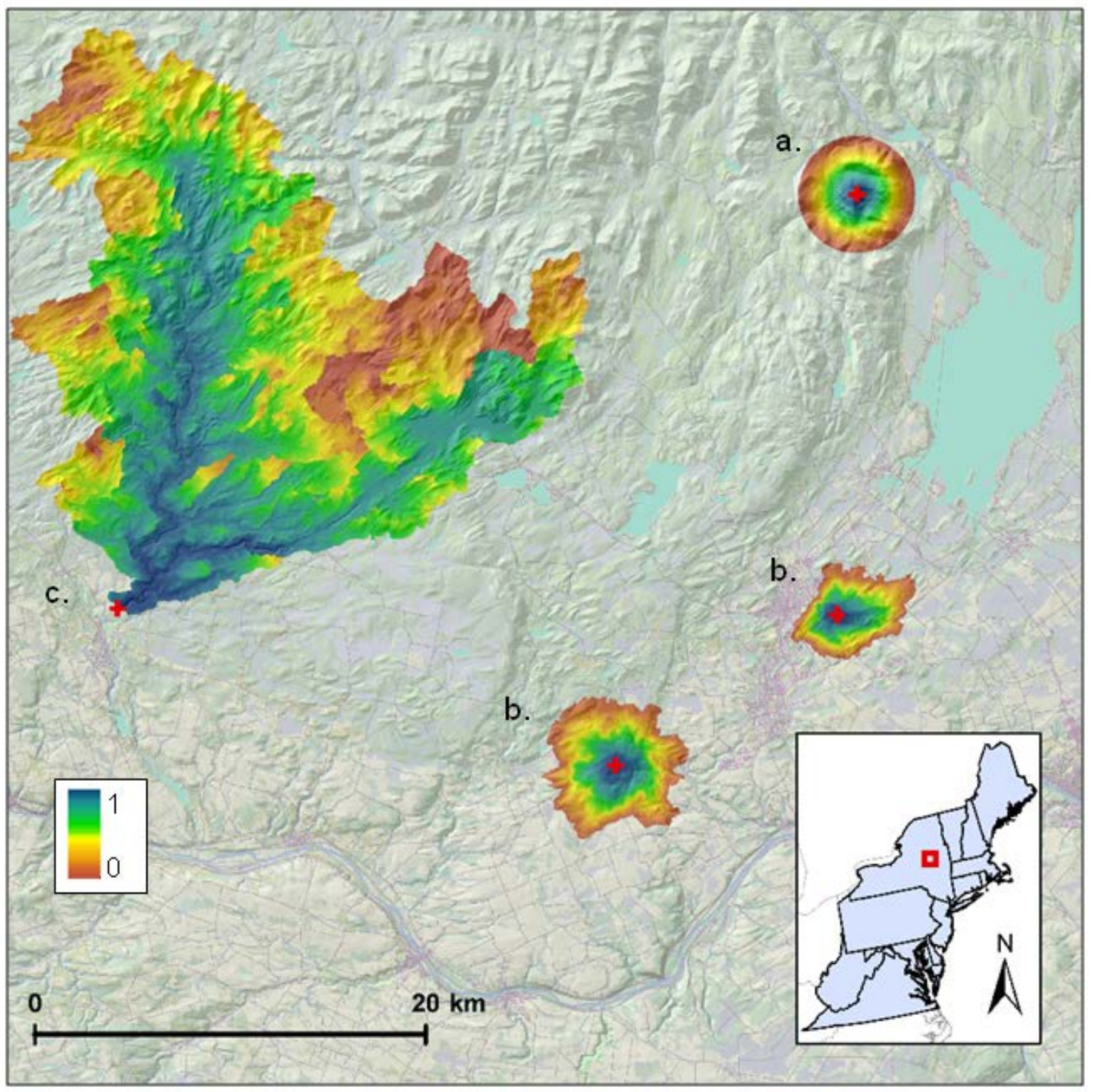

700 
Figure 3

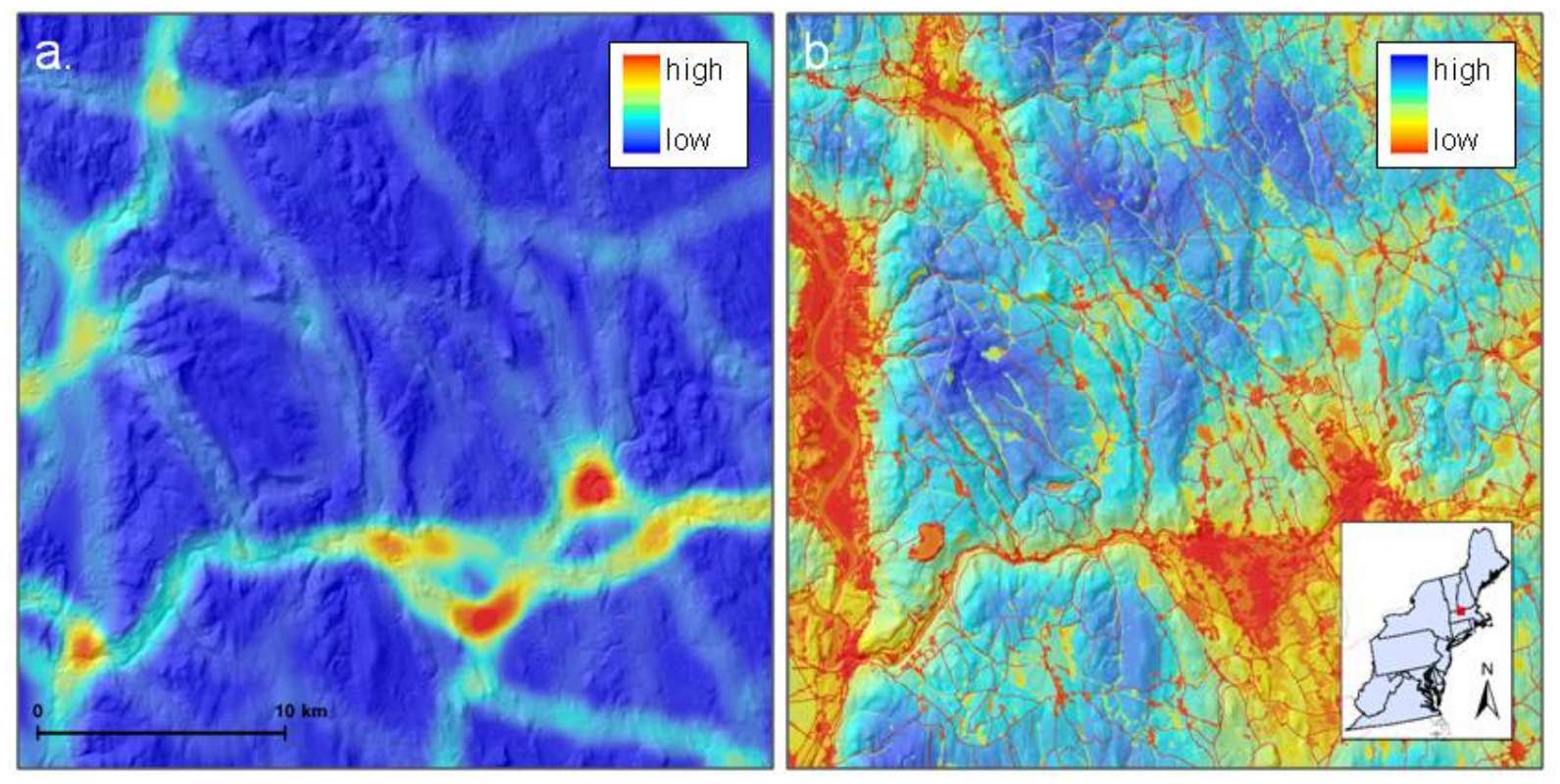


Figure 4
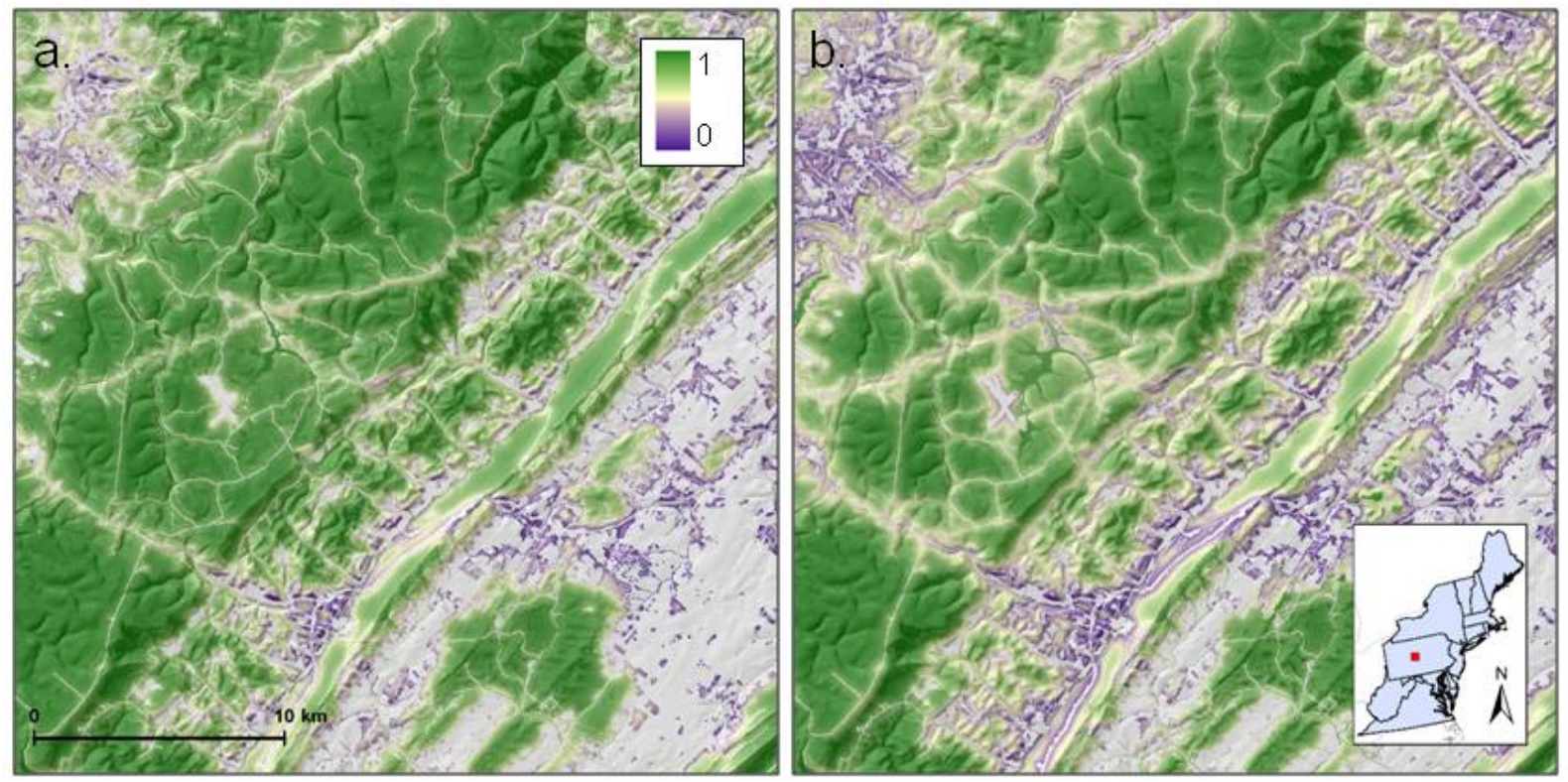

705 
Figure 5
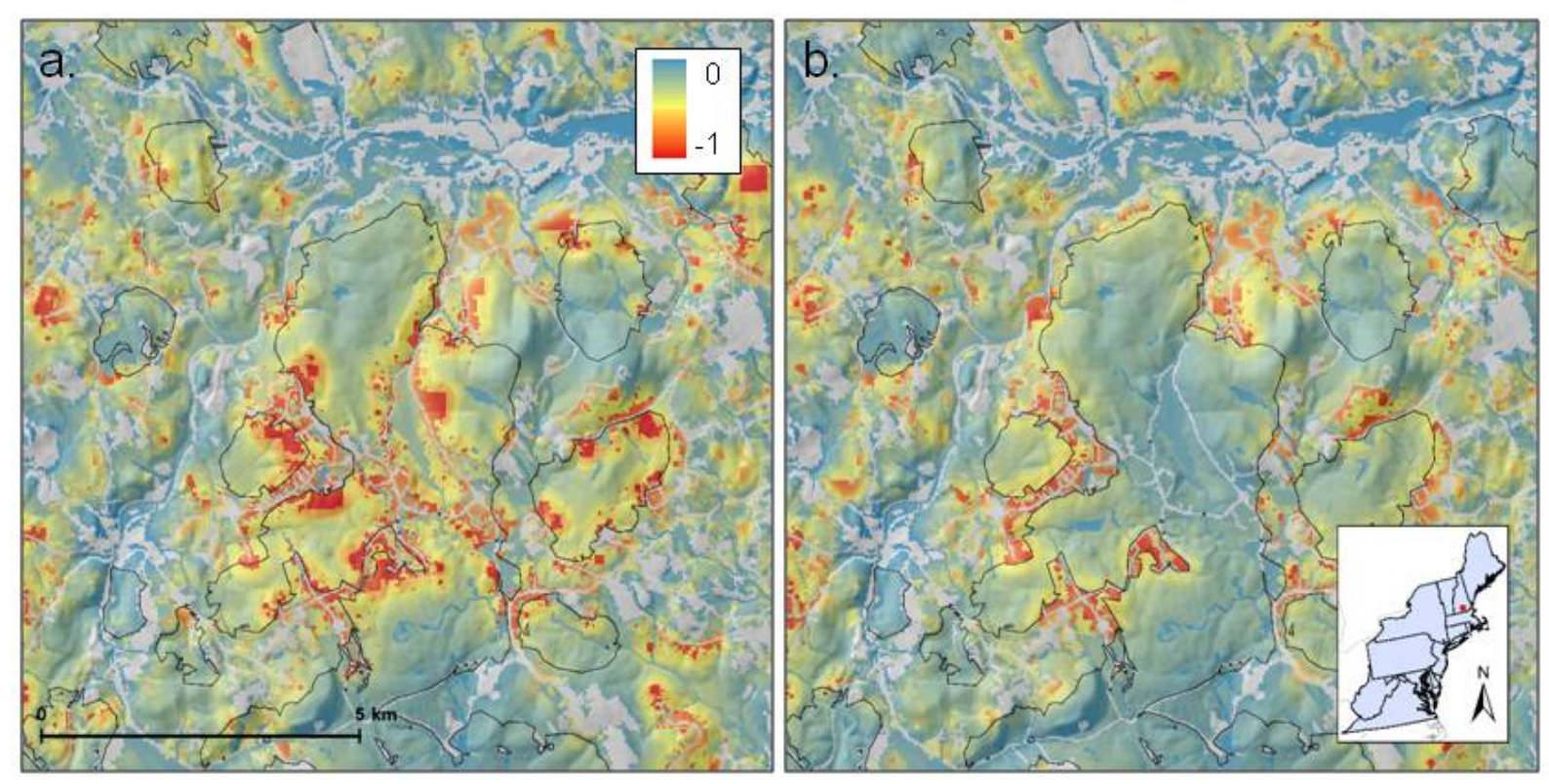
$710 \quad$ Figure 6

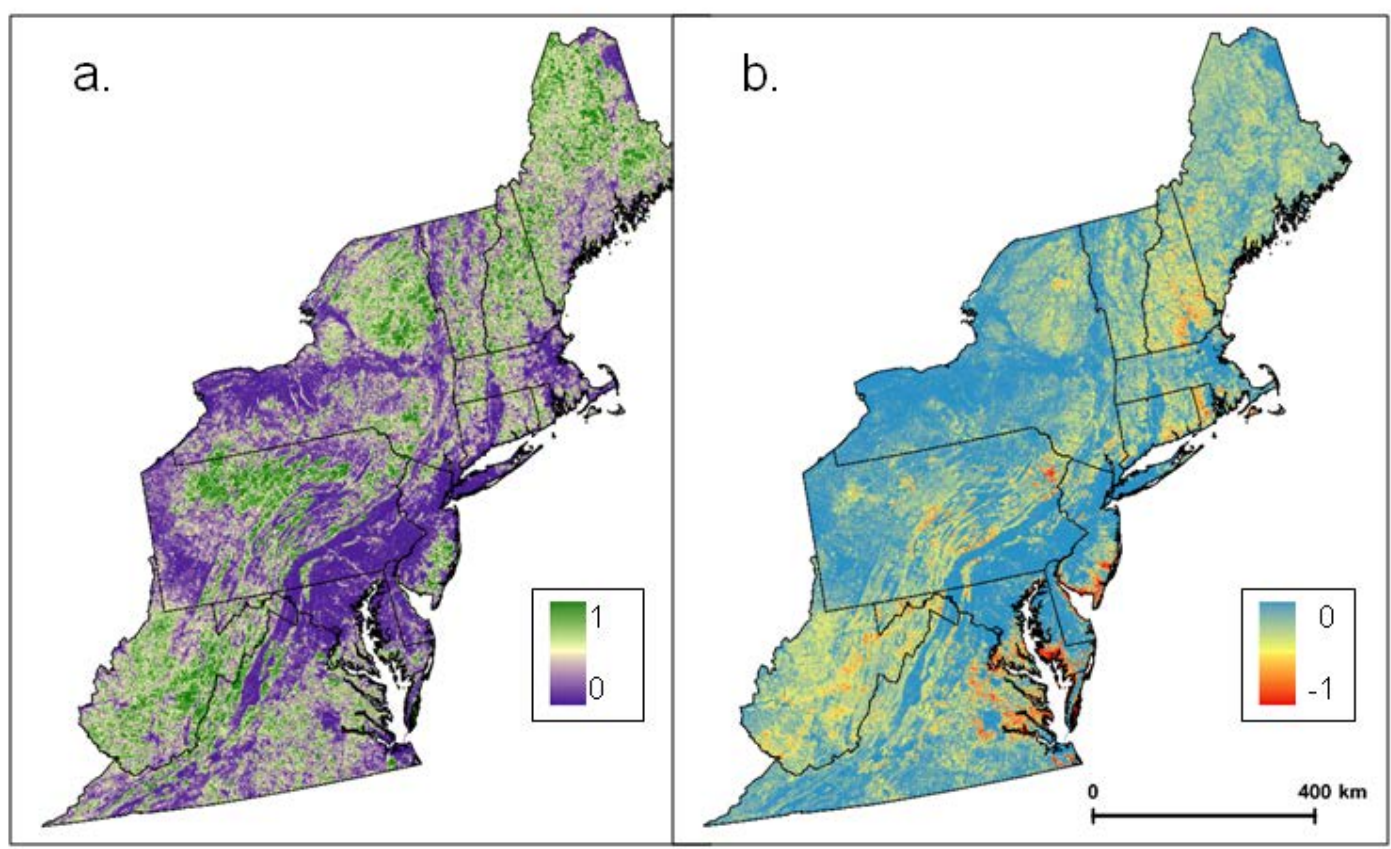




\section{References}

Addicott JF, Aho JM, Antolin MF, Padilla DK, Richardson JS, Soluk DA (1987) Ecological

715 neighborhoods: scaling environmental patterns. Oikos 49: 340-346.

Anderson M, Clark MG, Sheldon AO (2014) Estimating Climate Resilience for Conservation across Geophysical Settings. Conservation Biology 28: 959-970.

Anderson M, Ferree C (2010) Conserving the stage: climate change and the geophysical underpinnings of species diversity. PIOS ONE 5 (e11554) DOI: 10.371/journal/pne.0011554.

720 Andreasen JK, O’Neill RV, Noss R, Slosser NC (2001) Considerations for the development of a terrestrial index of ecological interity. Ecol Ind 1:21-35.

Beazley KF, Baldwin ED, Reining C (2010) Integrating Expert Judgment into Systematic Ecoregional Conservation Planning. Pages 235-255 In: Trombulak S., Baldwin R. (eds) Landscape-scale Conservation Planning. Springer, Dordrecht.

725 Beier P (2012) Conceptualizing and designing corridors for climate change. Ecological Restoration 30: 312-319.

Beier P, Brost B (2010) Use of land facets to plan for climate change: conserving the arenas, not the actors. Conservation Biology 24: 701-710.

Beier P, Hunter ML, Anderson M (2015) Special section: conserving nature's stage.

$730 \quad$ Conservation Biology 29: 613-617.

Belote RT, Dietz MS, Jenkins CN, McKinley PS, Irwin GH, Fullman TJ, Leppi JC, and Aplet GH (2017) Wild, connected, and diverse: building a more resilient system of protected areas. Ecological Applications 27: 1050-1056. 
Briers RA (2002) Incorporating connectivity into reserve selection procedures. Biological $735 \quad$ Conservation 103: 77-83.

Brown ED, Williams BK (2016) Ecological integrity assessment as a metric of biodiversity: are we measuring what we say we are? Biodiversity Conservation 25:1011-1035.

Ceballos G, Ehrlich PR, Barnosky AD, Garcia A, Pringle RM, Palmer TM (2015) Accelerated modern human-induced species losses: entering the sixth mass extinction. Science Advances $740 \quad 1: 1-5$

Cerdeira JO, Gaston KJ, Pinto LS (2005) Connectivity in priority area selection for conservation. Environmental Modeling and Assessment 10: 183-192.

Compton BW, McGarigal K, Cushman SA, Gamble LR (2007) A resistant-kernel model of connectivity for amphibians that breed in vernal pools. Conservation Biology 21: 788-799.

745 DeNormandie J, Corcoran C (2009) Losing ground beyond the footprint: patterns of development and their impact on the nature of Massachusetts. Fourth Edition of the Losing Ground Series, MassAudubon (http://www.massaudubon.org/content/ download/ 8601/149722/file/LosingGround_print.pdf).

Forman RTT, Sperling D, Bissonette JA, Clevenger AP, Cutshall CD, Dale VH, Fahrig L, 750 France R, Goldman CR, Heanue K, Jones JA, Swanson FJ, Turrentine T, Winter TC (2003) Road Ecology; Science and Solutions. Island Press, Covelo, CA. 504 pp.

Gunderson LH (2000) Ecological resilience-in theory and application. Annual Review of Ecology and Systematics 31: 425-439.

Haddad NM, Brudvig LA, Clobert J, Davies KF, Gonzalez A, Holt RD, Lovejoy TE, Sexton JO, 755 Austin MP, Collins CD, Cook WM, Damschen EI, Ewers RM, Foster BL, Jenkins CN, King 
AJ, Laurance WF, Levey DJ, Margules CR, Melbourne BA, Nicholls AO, Orrock JL, Song

D-X, Townshend JR (2015) Habitat fragmentation and its lasting impact on Earth's

ecosystems. Science Advances 1, e1500052.

Holling CS (1973) Resilience and stability of ecological systems. Annual Review of Ecology and $760 \quad$ Systematics 4: 1-23.

Holling CS (1996) Engineering resilience versus ecological resilience. In P. C. Schulze, editor. Engineering within ecological constraints. National Academy Press, Washington, D.C., USA.

Hunter Jr ML, Jacobson GL, Webb III T (1988) Paleoecology and the coarse-filter approach to maintaining biological diversity. Conservation Biology 2: 375-385.

765 Lentz EE, Stippa SR, Thieler ER, Plant NG, Gesch DB, Horton RM (2015) Evaluating coastal landscape response to sea-level rise in the northeastern United States-Approach and methods: U.S. Geological Survey Open-File Report 2014-1252, 26 p. http://dx.doi.org/10.3133/ofr20141252 ISSN 2331-1258 (online).

Lerner J, Mackey J, Casey F (2007) What's in Noah's wallet? Land conservation spending in the $770 \quad$ United States. BioScience 57: 419-423.

McGarigal, K., Compton, B.W., Plunkett, E.B., Deluca, W.V., and Grand, J. (2017). Designing sustainable landscapes project: documents and data products. [online] URL: https://scholarworks.umass.edu/designing_sustainable_landscapes/

McGarigal K, Plunkett EB, Willey L, Compton BW, Deluca WV, and Grand J. 2018. Modelling 775 urban growth in the northeastern United States: the SPRAWL model and the ecological impacts of urban growth. Ecological Modelling (In press). 
McGarigal K, Plunkett EB, Grand J, Compton BW, Portante T, Rolih K, Jackson SD (2013) Empirically derived indices of biotic integrity for forested wetlands, coastal salt marshes and wadable freshwaters streams in Massachusetts. Report to Massachusetts Department of $780 \quad$ Environmental Protection, September 15, 2013. 249 pp.

Newbold T, Hudson LN, Hill SLL, Contu S, Lysenko I, Senior RA, Börger L, Bennett DJ, Choimes A, Collen B, Day J, De Palma A, Díaz S, Echeverria-Londoño S, Edgar MJ, Feldman A, Garon M, Harrison MLK, Alhusseini T, Ingram DJ, Itescu Y, Kattge J, Kemp V, Kirkpatrick L, Kleyer M, Correia DLP, Martin CD, Meiri S, Novosolov M, Pan Y, Phillips HRP, Purves DW, Robinson A, Simpson J, Tuck SL, Weiher E, White HJ, Ewers RM, Mace GM, Scharlemann JPW, Purvis A (2015) Global effects of land use on local terrestrial biodiversity. Nature 520: 45-50.

Noss R (1996) Ecosystems as conservation targets. Trends in Ecology and Evolution. 11: 351.

Ortega-Huerta MA, Peterson AT (2004) Modelling spatial patterns of biodiversity for 790 conservation prioritization in North-eastern Mexico. Diversity and Distribution 10: 39-54. Parrish JD, Braun DP, Unnassch RS (2003) Are we conserving what we say we are? Measuring ecological integrity within protected areas: BioScience 53: 851-860.

Pereira HM, Leadley PW, Proenca V, Alkemade R, Scharlemann JPW, Fernandez-Manjarres JF, Araujo MB, Balvanera P, Biggs R, Cheung WWL, Chini L, Cooper HD, Gilman EL, 795 Guenette S, Hurtt GC, Huntington HP, Mace GM, Oberdorff T, Revenga C, Rodrigues P, Scholes RJ, Sumaila UR, Walpole M (2010) Scenarios for global biodiversity in the 21st century. Science 330: 1496-1501.

Pickett STA, Parker VT, Fiedler PL (1992) The new paradigm in ecology: implications for conservation above the species level. Pages 65-88. In: P.L. Fiedler and S.K. Jain, editors. 
800 Conservation biology: theory and practice of nature conservation and management. Chapman and Hall Press. New York. U.S.A..

Pimm SL, Russell GJ, Gittleman JL, Brooks TM (1995) The future of biodiversity. Science 269: $347-350$.

Randhir TO, O'Connor R, Penner PR, Goodwin DW (2001) A watershed-based land

805 prioritization model for water supply protection. Forest Ecology and Management 143: 4756.

Sala OE, Chapin III FC, Armesto JJ, Berlow E, Bloomfield J, Dirzo R, Huber-Sanwald E, Huenneke LF, Jackson RB, Kinzig A, Leemans R, Lodge DM, Mooney HA, Oesterheld M, Poff NL, Sykes MT, Walker BH, Walker M, Wall DH (2000) Global biodiversity scenarios

$810 \quad$ for the year 2100. Science 287: 1770-1774.

Sanderson EW, Jaiteh M, Levy MA, Redford KH, Wannebo AV, Woolmer G (2002) The human footprint and the last of the wild. Bioscience 52: 891-904.

Scott JM, Davis F, Csuti B, Noss R, Butterfield B, Groves C, Anderson H, Caicco S, D’Erchia F, Edwards Jr. TC, Ulliman J, Wright RG (1993) GAP analysis: a geographic approach to 815 protection of biological diversity. Wildlife Monographs 123: 1-41.

Silverman BW (1986) Density estimation for statistics and data analysis. Chapman \& Hall, London.

Soulé ME, Terborgh J (eds) (1999) Continental Conservation: scientific foundations of regional reserve networks. Island Press. Washington, D.C., U.S.A..

820 Theobald DM (2013) A general model to quantify ecological integrity for landscape assessments and US application. Landscape ecology 28: 1859-1874. 
Tierney GL, Faber-Langendoen D, Mitchell BR, Shriver WG, Gibbs JP (2009) Monitoring and evaluating the ecological integrity of forest ecosystems: Frontiers in Ecology and the Environment 7: 308-316.

825 Turner MG, Gardner RH (2015) Landscape ecology in theory and practice. Springer-Verlag, New York. 482 pp.

Venter O, Sanderson EW, Magrach A, Allan JR, BeherJ, Jones KR, Possingham HP, Laurance WF, Wood P, Fekete BM, Levy MA, Watson JEM (2016) Sixteen years of change in the global terrestrial human footprint and implications for biodiversity conservation. Nature

830 Communications 7:12558. doi:10.1038/ncomms12558.

Williams PH, Margules CR, Hilbert DW (2002) Data requirements and data sources for biodiversity priority area selection. Journal of Biosciences 27: 327-338.

Wurtzebach Z, Schultz C (2016) Measuring ecological integrity: history, practical applications, and research opportunities. BioScience 66: 446-457.

835 Zeller KA, McGarigal K, Whiteley AR (2012) Estimating landscape resistance to movement: a review. Landscape Ecology 27: 777-797. 


\section{APPENDICES}

\section{A landscape index of ecological integrity: applications in landscape conservation}

Kevin McGarigal, Bradley W. Compton, Ethan B. Plunkett, William V. Deluca, Joanna Grand, Eduard Ene, and Scott D. Jackson

\section{Appendix A. Ecological settings variables.}

Links to detailed documentation for each of the ecological settings variables (i.e., biophysical site descriptors used in the calculation of the individual ecological integrity metrics and/or in the calculation of the final rescaled index of ecological integrity) developed for the northeastern United States. All settings variables exist as $30 \mathrm{~m}$ rasters. Documents include a general

10 description of the layer, considerations for the use and interpretation of the layer, derivation of the layer, including data sources and algorithm, and metadata for the distributed product. The settings variables are arbitrarily grouped into broad classes for organizational purposes.

\begin{tabular}{l|l}
\hline Ecological settings variable & Link to detailed documentation \\
\hline $\begin{array}{l}\text { Energy } \\
\text { Incident solar radiation }\end{array}$ & $\frac{\text { http://jamba.provost.ads.umass.edu/web/lcc/DSL_docu }}{\underline{\text { mentation_sun.pdf }}}$ \\
Growing season degree-days & $\frac{\text { http://jamba.provost.ads.umass.edu/web/lcc/DSL_docu }}{\text { mentation_temperature.pdf }}$ \\
Minimum winter temperature & $\underline{\text { http://jamba.provost.ads.umass.edu/web/lcc/DSL_docu }}$ \\
Heat Index 35 & $\underline{\text { mentation_streamtemp.pdf }}$ \\
Stream temperature & $\underline{\text { http://jamba.provost.ads.umass.edu/web/lcc/DSL_docu }}$ \\
Chemical \& physical substrate \\
Water salinity
\end{tabular}




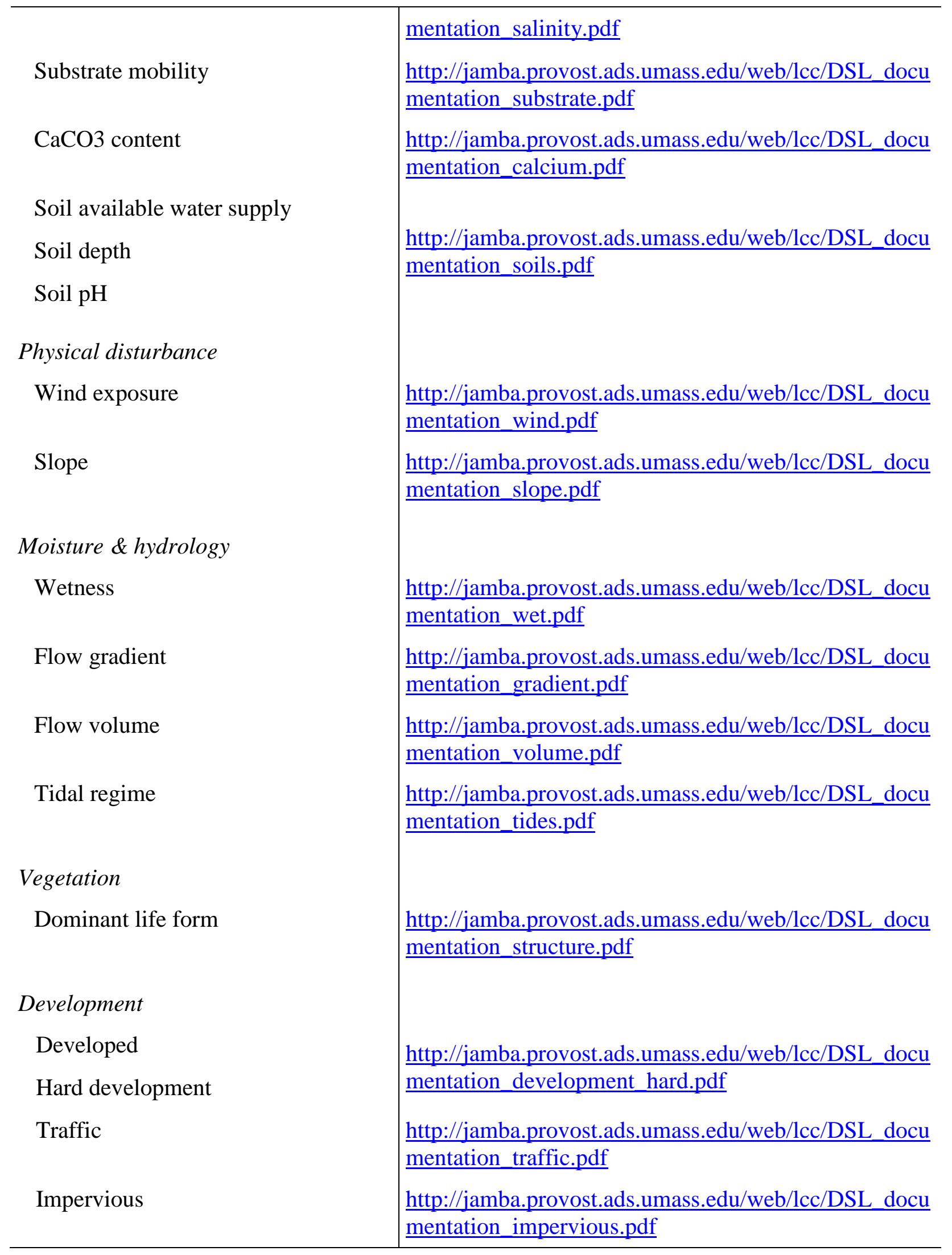


Terrestrial barriers

Aquatic barriers
http://jamba.provost.ads.umass.edu/web/lcc/DSL_docu mentation_tbarriers.pdf

http://jamba.provost.ads.umass.edu/web/lcc/DSL_docu mentation_abarriers.pdf 


\section{Appendix B. Hierarchical classification of formations and ecological systems}

Hierarchical classification of formations and ecosystems (Anderson et al. 2013, Ferree and Anderson 2013, Olivero-Sheldon et al. 2014) as used in our coarse-filter ecological integrity assessment in the northeastern United States. The formations are used for convenience to group the ecological systems into broader classes for purposes of assigning roughness and runoff

20 coefficients in the watershed kernels (Appendix D) and weighting the individual integrity metrics in the calculation of the index of ecological integrity (IEI) and the index of ecological impact (ecoImpact) (Appendix F). See references below for a description of the ecological systems.

\begin{tabular}{ll}
\hline Formation & Ecosystem \\
\hline Alpine & Acadian-Appalachian Alpine Tundra \\
Boreal Upland Forest & Acadian Low Elevation Spruce-Fir-Hardwood Forest \\
Boreal Upland Forest & Acadian Sub-boreal Spruce Flat \\
Boreal Upland Forest & Acadian-Appalachian Montane Spruce-Fir-Hardwood \\
Boreal Upland Forest & Forest \\
Cliff \& Rock & Central and Southern Appalachian Spruce-Fir Forest \\
Cliff \& Rock & Acidic Cliff and Talus \\
Cliff \& Rock & Calcareous Cliff and Talus \\
Coastal Scrub-Herb & Circumneutral Cliff and Talus \\
Coastal Scrub-Herb & Atlantic Coastal Plain Beach and Dune \\
Coastal Scrub-Herb & Great Lakes Dune and Swale \\
Grassland \& Shrubland & North Atlantic Coastal Plain Heathland and Grassland \\
Grassland \& Shrubland & Acidic Rocky Outcrop \\
Grassland \& Shrubland & Appalachian Shale Barrens \\
Grassland \& Shrubland & Calcareous Rocky Outcrop \\
\hline
\end{tabular}




\begin{tabular}{|c|c|}
\hline Formation & Ecosystem \\
\hline Grassland \& Shrubland & Eastern Serpentine Woodland \\
\hline Grassland \& Shrubland & Great Lakes Alvar \\
\hline Grassland \& Shrubland & Shrubland \& grassland (NLCD 52/71) \\
\hline Grassland \& Shrubland & Mafic Glade and Barrens \\
\hline Grassland \& Shrubland & Southern Appalachian Grass and Shrub Bald \\
\hline Grassland \& Shrubland & $\begin{array}{l}\text { Southern Ridge and Valley Calcareous Glade and } \\
\text { Woodland }\end{array}$ \\
\hline Northeastern Upland Forest & Allegheny-Cumberland Dry Oak Forest and Woodland \\
\hline Northeastern Upland Forest & Appalachian (Hemlock)-Northern Hardwood Forest \\
\hline Northeastern Upland Forest & Central and Southern Appalachian Montane Oak Forest \\
\hline Northeastern Upland Forest & Central Appalachian Dry Oak-Pine Forest \\
\hline Northeastern Upland Forest & Central Appalachian Pine-Oak Rocky Woodland \\
\hline Northeastern Upland Forest & Central Atlantic Coastal Plain Maritime Forest \\
\hline Northeastern Upland Forest & Glacial Marine \& Lake Mesic Clayplain Forest \\
\hline Northeastern Upland Forest & Laurentian-Acadian Northern Hardwood Forest \\
\hline Northeastern Upland Forest & Laurentian-Acadian Northern Pine-(Oak) Forest \\
\hline Northeastern Upland Forest & Laurentian-Acadian Pine-Hemlock-Hardwood Forest \\
\hline Northeastern Upland Forest & Laurentian-Acadian Red Oak-Northern Hardwood Forest \\
\hline Northeastern Upland Forest & North Atlantic Coastal Plain Hardwood Forest \\
\hline Northeastern Upland Forest & North Atlantic Coastal Plain Maritime Forest \\
\hline Northeastern Upland Forest & North Atlantic Coastal Plain Pitch Pine Barrens \\
\hline Northeastern Upland Forest & North-Central Interior Beech-Maple Forest \\
\hline Northeastern Upland Forest & Northeastern Coastal and Interior Pine-Oak Forest \\
\hline Northeastern Upland Forest & Northeastern Interior Dry-Mesic Oak Forest \\
\hline Northeastern Upland Forest & Northeastern Interior Pine Barrens \\
\hline Northeastern Upland Forest & Piedmont Hardpan Woodland and Forest \\
\hline Northeastern Upland Forest & Pine plantation / Horticultural pines \\
\hline Northeastern Upland Forest & South-Central Interior Mesophytic Forest \\
\hline
\end{tabular}




\begin{tabular}{|c|c|}
\hline Formation & Ecosystem \\
\hline Northeastern Upland Forest & Southern and Central Appalachian Cove Forest \\
\hline Northeastern Upland Forest & Southern Appalachian Low Elevation Pine Forest \\
\hline Northeastern Upland Forest & Southern Appalachian Montane Pine Forest and Woodland \\
\hline Northeastern Upland Forest & Southern Appalachian Northern Hardwood Forest \\
\hline Northeastern Upland Forest & Southern Appalachian Oak Forest \\
\hline Northeastern Upland Forest & Southern Atlantic Coastal Plain Mesic Hardwood Forest \\
\hline Northeastern Upland Forest & $\begin{array}{l}\text { Southern Atlantic Coastal Plain Upland Longleaf Pine } \\
\text { Woodland }\end{array}$ \\
\hline Northeastern Upland Forest & Southern Piedmont Dry Oak-Pine Forest \\
\hline Northeastern Upland Forest & Southern Piedmont Mesic Forest \\
\hline Northeastern Upland Forest & $\begin{array}{l}\text { Southern Ridge and Valley / Cumberland Dry Calcareous } \\
\text { Forest }\end{array}$ \\
\hline Northeastern Wetland & $\begin{array}{l}\text { Atlantic Coastal Plain Blackwater/Brownwater Stream } \\
\text { Floodplain Forest }\end{array}$ \\
\hline Northeastern Wetland & Central Appalachian Stream and Riparian \\
\hline Northeastern Wetland & $\begin{array}{l}\text { Central Atlantic Coastal Plain Non-riverine Swamp and } \\
\text { Wet Hardwood Forest }\end{array}$ \\
\hline Northeastern Wetland & $\begin{array}{l}\text { Central Interior Highlands and Appalachian Sinkhole and } \\
\text { Depression Pond }\end{array}$ \\
\hline Northeastern Wetland & Glacial Marine \& Lake Wet Clayplain Forest \\
\hline Northeastern Wetland & High Allegheny Headwater Wetland \\
\hline Northeastern Wetland & Laurentian-Acadian Alkaline Conifer-Hardwood Swamp \\
\hline Northeastern Wetland & Laurentian-Acadian Freshwater Marsh \\
\hline Northeastern Wetland & Laurentian-Acadian Large River Floodplain \\
\hline Northeastern Wetland & Laurentian-Acadian Wet Meadow-Shrub Swamp \\
\hline Northeastern Wetland & North Atlantic Coastal Plain Basin Peat Swamp \\
\hline Northeastern Wetland & $\begin{array}{l}\text { North Atlantic Coastal Plain Basin Swamp and Wet } \\
\text { Hardwood Forest }\end{array}$ \\
\hline Northeastern Wetland & North Atlantic Coastal Plain Pitch Pine Lowland \\
\hline Northeastern Wetland & North Atlantic Coastal Plain Stream and River \\
\hline
\end{tabular}




\begin{tabular}{ll}
\hline Formation & Ecosystem \\
\hline Northeastern Wetland & North Atlantic Coastal Plain Tidal Swamp \\
Northeastern Wetland & North-Central Appalachian Acidic Swamp \\
Northeastern Wetland & North-Central Appalachian Large River Floodplain \\
Northeastern Wetland & North-Central Interior and Appalachian Rich Swamp \\
Northeastern Wetland & North-Central Interior Large River Floodplain \\
Northeastern Wetland & North-Central Interior Wet Flatwoods \\
Northeastern Wetland & Northern Appalachian-Acadian Conifer-Hardwood Acidic \\
Northeastern Wetland & Swamp \\
Northeastern Wetland & Piedmont Upland Depression Swamp \\
Northeastern Wetland & Piedmont-Coastal Plain Freshwater Marsh \\
Northeastern Wetland & Piedmont-Coastal Plain Large River Floodplain \\
Northeastern Wetland & Piedmont-Coastal Plain Shrub Swamp \\
Northeastern Wetland & Ruderal Shrub Swamp \\
Northeastern Wetland & Southern Atlantic Coastal Plain Tidal Wooded Swamp \\
Northeastern Wetland & Southern Piedmont Lake Floodplain Forest \\
Peatland & Southern Piedmont Small Floodplain and Riparian Forest \\
Peatland & Acadian Maritime Bog \\
Peatland & Atlantic Coastal Plain Northern Bog \\
Peatland & Atlantic Coastal Plain Peatland Pocosin and Canebrake \\
Peatland & Boreal-Laurentian Bog \\
Peatland & Boreal-Laurentian-Acadian Fen \\
Lentic & North-Central Interior and Appalachian Acidic Peatland \\
Lentic & Great Lakes \\
Lentic & Lentic \\
Lentic & Very Cold Lake \\
Lentic & Cold Lake \\
Lentic & Cold Pond \\
& Cool Eutrophic Lake \\
\hline &
\end{tabular}




\begin{tabular}{|c|c|}
\hline Formation & Ecosystem \\
\hline Lentic & Cool Oligo-Mesotrophic Lake \\
\hline Lentic & Cool Eutrophic Pond \\
\hline Lentic & Cool Oligo-Mesotrophic Pond \\
\hline Lentic & Warm Eutrophic Lake \\
\hline Lentic & Warm Oligo-Mesotrophic Lake \\
\hline Lentic & Warm Eutrophic Pond \\
\hline Lentic & Warm Oligo-Mesotrophic Pond \\
\hline Lentic & Small Pond \\
\hline Lotic & Lotic \\
\hline Stream (headwater/creek) & Stream (headwater/creek) cold high \\
\hline Stream (headwater/creek) & Stream (headwater/creek) cold moderate \\
\hline Stream (headwater/creek) & Stream (headwater/creek) cold low \\
\hline Stream (headwater/creek) & Stream (headwater/creek) cool high \\
\hline Stream (headwater/creek) & Stream (headwater/creek) cool moderate \\
\hline Stream (headwater/creek) & Stream (headwater/creek) cool low \\
\hline Stream (headwater/creek) & Stream (headwater/creek) warm high \\
\hline Stream (headwater/creek) & Stream (headwater/creek) warm moderate \\
\hline Stream (headwater/creek) & Stream (headwater/creek) warm low \\
\hline Stream (small) & Stream (small) cold moderate \\
\hline Stream (small) & Stream (small) cold low \\
\hline Stream (small) & Stream (small) cool moderate \\
\hline Stream (small) & Stream (small) cool low \\
\hline Stream (small) & Stream (small) warm moderate \\
\hline Stream (small) & Stream (small) warm low \\
\hline Stream (medium) & Stream (medium) cold \\
\hline Stream (medium) & Stream (medium) cool \\
\hline Stream (medium) & Stream (medium) warm \\
\hline Stream (large) & Stream (large) cool \\
\hline
\end{tabular}




\begin{tabular}{|c|c|}
\hline Formation & Ecosystem \\
\hline Stream (large) & Stream (large) warm \\
\hline Stream (tidal) & Freshwater Tidal Riverine \\
\hline Estuarine Intertidal & Estuarine Subtidal Sheltered \\
\hline Estuarine Intertidal & Estuarine Intertidal Aquatic Bed \\
\hline Estuarine Intertidal & Estuarine Intertidal Emergent \\
\hline Estuarine Intertidal & Estuarine Intertidal Forested \\
\hline Estuarine Intertidal & Estuarine Intertidal Reef \\
\hline Estuarine Intertidal & Estuarine Intertidal Rocky Shore \\
\hline Estuarine Intertidal & Estuarine Intertidal Scrub Shrub \\
\hline Estuarine Intertidal & Estuarine Intertidal Unconsolidated Shore \\
\hline Estuarine Subtidal & Estuarine Subtidal Aquatic Bed \\
\hline Estuarine Subtidal & Estuarine Subtidal Unconsolidated Bottom \\
\hline Marine Intertidal & Marine Intertidal Aquatic Bed \\
\hline Marine Intertidal & Marine Intertidal Rocky Shore \\
\hline Marine Intertidal & Marine Intertidal Unconsolidated Shore \\
\hline Marine Subtidal & Marine Subtidal Aquatic Bed \\
\hline Marine Subtidal & Marine Subtidal Unconsolidated Bottom \\
\hline Agriculture & Cultivated crops \\
\hline Agriculture & Pasture/hay \\
\hline Developed & Abandoned train \\
\hline Developed & Active train \\
\hline Developed & Barren land \\
\hline Developed & Culvert/bridge \\
\hline Developed & Dam \\
\hline Developed & Developed- high intensity \\
\hline Developed & Developed- medium intensity \\
\hline Developed & Developed- low intensity \\
\hline Developed & Developed- open space \\
\hline
\end{tabular}




\begin{tabular}{ll}
\hline Formation & Ecosystem \\
\hline Developed & Motorway \\
Developed & Primary road \\
Developed & Secondary road \\
Developed & Tertiary road \\
Developed & Local road \\
Developed & Track \\
\hline
\end{tabular}

\section{References}

Anderson MG, Clark M, Ferree CE, Jospe A, Olivero-Sheldon A, Weaver KJ (2013) Northeast Habitat Guides: A companion to the terrestrial and aquatic habitat maps. The Nature Conservancy, Eastern Conservation Science, Eastern Regional Office. Boston, MA. http://nature.ly/HabitatGuide.

30 Ferree C, Anderson MG (2013) A Map of Terrestrial Habitats of the Northeastern United States: Methods and Approach. The Nature Conservancy, Eastern Conservation Science, Eastern Regional Office. Boston, MA.

Olivero A, Anderson MG (2013) Aquatic Habitat Classification System. The Nature Conservancy, Eastern Conservation Science, Eastern Regional Office. Boston, MA.

35 Olivero-Sheldon A, Jospe A, Anderson MG (2014) Northeast lake and pond classification. The Nature Conservancy, Eastern Conservation Science, Eastern Regional Office. Boston, MA. 


\section{Appendix C. Detailed description of the resistant kernel algorithm used to define the ecological neighborhood for the connectedness (resiliency) metric.}

40 The resistant kernel is derived as follows (Fig. C1):

Step 1.-The first step is to derive a resistance (or cost) surface for the neighborhood surrounding a focal cell, and there are two different approaches that can be used to create a resistance surface for use in a resistant kernel:

1. In the first case, the resistance surface is derived from a single categorical raster (e.g., land cover types; Fig. C1-A). In this case, we assign a cost to each land cover type. Note, the cost matrix (Fig. C1-B) represents the relative cost of moving through each patch type from an initial patch type, and it need not be symmetrical. For example, the cost matrix in figure C1-B is read as follows. The row heading represents the "from" patch type, and the column heading represents the "to" patch type. Thus, the first row of the matrix is interpreted as: from a focal cell of patch type A, the cost of moving through a cell of the same patch type (A) is one (the minimum cost); the cost of moving through a cell of patch type B is two (i.e., two times more costly than moving through a cell of patch type A); the cost of moving through a cell of patch type C is three (i.e., three times more costly than A), and so on. The costs are user-defined and can take on any values, as long as the minimum cost (and the cost of moving through a cell of the same patch type) is one. Thus, the diagonal elements of the matrix are always set to one, but the off-diagonals can take on any value greater than one. For a focal cell, we generate a resistance (or cost) surface by assigning the relevant cost to each cell based on the cost matrix (Fig. C1-C). For example, the focal cell in figure C1-C is of patch type A, so the costs assigned to each cell are based 
on the information in the first row of the cost matrix corresponding to "from" patch type A. Note, the resistance surface will change depending on the patch type of the focal cell.

2. In the second case, the resistance surface is derived from one or more continuous rasters (e.g., representing continuous ecological variables). In this case, we compute the Euclidean distance in ecological space between the focal cell and each neighboring cell. Note, Euclidean distance is easily computed for a single continuous variable as the absolute value of the difference between cell values, but this is easily extended to multivariate ecological distance for two or more variables. In this case, the variables are standardized (e.g., range rescaled 0-1, z-scores) and (optionally) weighted before computing the Euclidean distance. Next, we convert the (weighted) Euclidean distance to cost based on a user-specified transformation function. For example, we might range-rescale Euclidean distance by stretching or shrinking it to fit the desired cost range (e.g., 1-20). Alternatively, we might apply a nonlinear transformation such as a logistic function or power function. Thus, for a focal cell, we generate a resistance surface by assigning the transformed Euclidean distance to each neighboring cell. Note, as in the first case described above, the resistance surface will change depending the ecological setting of the focal cell.

It is important to recognize the dynamic nature of the resistance surface approach described above, whereby the resistance surface changes depending the land cover type (case 1) or ecological setting (case 2) of the focal cell and its unique ecological neighborhood. Thus, each focal cell has a unique resistance surface. 
80 Step 2.-The second step is to assign to the focal cell a "bank account" based on the width of the user-specified standard kernel, and spread outward to adjacent cells iteratively, depleting the bank account at each step by the minimum cost of spreading to each cell (Fig. C1-D). For illustrative purposes, suppose that the raster cell size in figure C1-A is $10 \mathrm{~m}$ and we wish to create a resistant Gaussian kernel with a bandwidth $h$ (equal to one standard deviation) of $30 \mathrm{~m}$

85 (three cells). Further, suppose that we want the Gaussian kernel to extend outward to no more three standard deviations ( $3 h$; $90 \mathrm{~m}$ or nine cells), since beyond that distance the landscape has only a trivial influence on the focal cell. Given these parameters, we start with a bank account of nine, since at the minimum cost of one of moving through a single cell, the kernel will extend outward nine cells. Starting with a bank account of nine in the focal cell, if we move to an

90 adjacent cell of patch type F (cost of 10, Fig. C1-B), we reduce the bank account by ten and assign a balance of zero (since negative accounts are not allowed) to that cell. This means that we use up our entire bank account if we attempt to move through a cell of patch type F and can spread no further from that cell. On the other hand, if we move to an adjacent cell of patch type A (cost of one; Fig. C1-B), we reduce the bank account by one and assign a balance of eight to

95 that cell. For simplicity in this illustration, diagonal paths are treated the same as orthogonal paths; in the model diagonal costs are multiplied by the square root of $2(=1.4)$. Note, an artefact of weighting the diagonal neighbors in this manner and using a cellular automata approach (in which distance is measured in a zig-zag like manner instead of straight line) is an octagonal shaped standard kernel. This process is repeated iteratively, spreading outward in turn from each

100 visited cell, each time finding the least cost of getting to that cell from any of its neighbors, until the balance reaches zero. This produces a "functional proximity" surface representing the proximity of every cell to the focal cell within a threshold proximity distance. Note the 
difference between functional proximity and least-cost path distance. Functional proximity decreases as you move away from the focal cell, whereas least-cost path distance increases -

105 they are complementary measures of distance. In addition, note that the proximity surface has embedded within it the least-cost path to each cell.

Step 3.-The last step is to convert the cell values in the proximity surface to weights based on the specified kernel function. First, transform the proximity values into the number of units from the focal cell by subtracting the proximity value from the initial bank account, such that in our

110 example, a proximity value of nine (focal cell) is equal to zero and a proximity value of zero (cells at the periphery of the kernel) is equal to nine. Second, based on the specified kernel function, compute the probability density for the value derived above. For example, for a Gaussian kernel, compute the probability density for each value based on a normal distribution with a mean of zero and standard deviation of three. Third, divide these values by a constant

115 equal to the sum of the values above for a standard kernel (or resistant kernel in a non-resistant landscape). Note, the constant above ensures that the volume of a standard kernel (or resistant kernel in a non-resistant landscape) is equal to one. The resulting surface is the resistant kernel and its volume is always less than or equal to one (Fig. C1-E). 

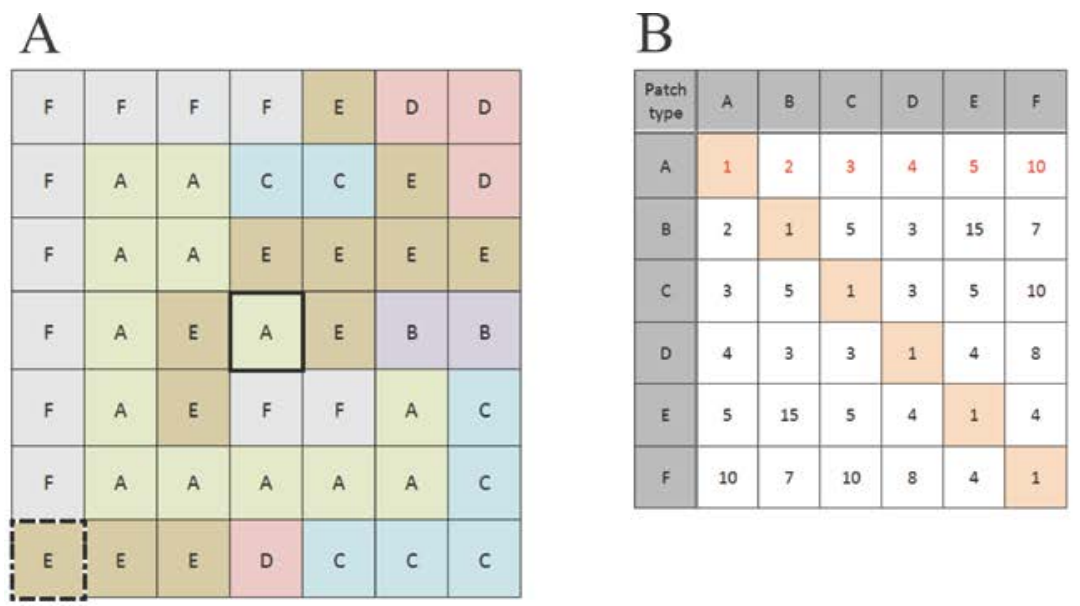

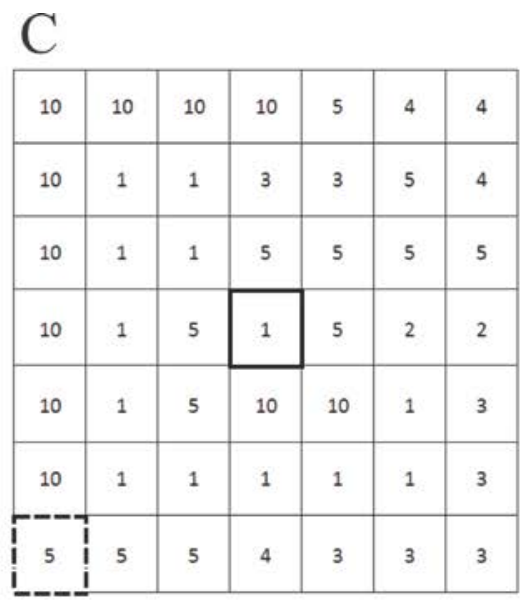

D

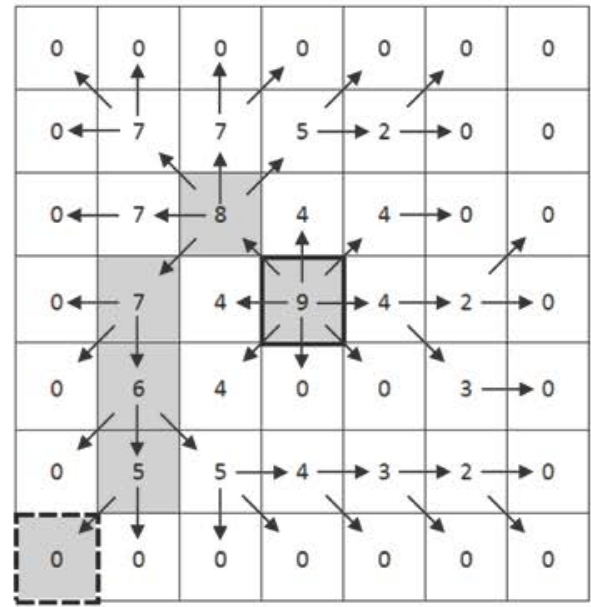

E

\begin{tabular}{|l|l|l|l|l|l|l|}
\hline .0016 & .0016 & .0016 & .0016 & .0016 & .0016 & .0016 \\
\hline .0016 & .1127 & .1127 & .0578 & .0092 & .0016 & .0016 \\
\hline .0016 & .1127 & .1331 & .0351 & .0351 & .0016 & .0016 \\
\hline .0016 & .1127 & .0351 & .1407 & .0351 & .0092 & .0016 \\
\hline .0016 & .0853 & .0351 & .0016 & .0016 & .0190 & .0016 \\
\hline .0016 & .0578 & .0578 & .0351 & .0190 & .0092 & .0016 \\
\hline .0016 & .0016 & .0016 & .0016 & .0016 & .0016 & .0016 \\
\hline
\end{tabular}

Figure C-1. Illustration of the resistant kernel algorithm as applied to a focal cell (outlined in

120 bold in the center of the image. (A) categorical land cover map in which each land cover type is represented by a unique letter. (B) matrix of ecological resistance values for each pairwise combination of land cover types, in which the land cover of the focal cell is given by the row and the columns represent the resistance values to move from the focal cell land cover type through each of the other land cover types; note the diagonals are 1 which is the minimum resistance. (C)

125 the original raster land cover map translated into a resistance surface relative to the land cover of the focal cell derived by applying the corresponding values from the matrix shown in $\mathrm{B}$. (D) functional proximity distance surface representing the functional distance between each cell and 
the focal cell in the center, derived by starting with a "bank account" of 10 units in the focal cell and spreading outward, discounting the value at each step by the resistance shown in C; the

130 arrows indicate the "least cost path" spread. (E) the final resistant kernel surface derived by a Gaussian transformation of the surface in D (see text for details). 


\section{Appendix D. Description of the watershed kernel used to define the ecological neighborhood for the watershed-based ecological integrity metrics.}

135 For a given focal aquatic cell, we determine its watershed by identifying all the cells that eventually flow to that cell based on the flow grid derived from the digital elevation model. For each cell within the watershed of the focal cell, we compute the time-of-flow based on the model derived by Randhir et al. (2001), but modified slightly for our use, as follows:

If the cell is in a stream channel, use revised Manning's equation:

140

$$
t=\frac{L N}{1.49 R_{h}^{\frac{2}{3}} \sqrt{S}}
$$

else, we use the Kinematic Wave equation:

$$
t=\frac{0.933 \times(L N)^{0.6}}{(C l)^{0.4} \times S^{0.3}}
$$

Where:

$$
t=\text { time-of-flow }
$$

145

$$
L=\text { cell width (cell size } \times 1.4 \text { for diagonal flow) }
$$$$
N=\text { roughness coefficient (based on land use) }
$$$$
C=\text { runoff coefficient (based on land use) }
$$

$S=$ slope

$I=$ rainfall intensity, inches/hour 
In the "revised” Manning's equation, 1.49 is $k / N$, where $k$ is a unit-conversion constant, and $N$ is the roughness constant for the stream channel. The roughness and runoff coefficients ( $N$ and $C$ ) are parameterized uniquely for each land cover type, or ecological formation (groups of related ecological systems) in our case (Table D1). Rainfall intensity can be estimated for each location 155 by interpolation of meteorological data or simply assigned the average for the project area (e.g., $2 \mathrm{in} / \mathrm{h}$ for the Ware River watershed in Massachusetts). Hydraulic radius $\left(R_{h}\right)$ can be approximated by the stream depth (because the wetted perimeter can be approximated by stream width), but because streams all have a very short time of flow compared to everything else and we have no legitimate way of estimating stream depth, we set $R_{h}$ to a constant of $1 \mathrm{~m}$.

160 Table D1. Roughness and runoff coefficients used in the watershed kernel based on the model derived by Randhir et al. (2001). Coefficients are given by ecological formation or ecosystem (see Appendix B) and were based on coefficients used in Randhir et al. (2001), obtained from the author, and cross-walked to our formations and ecosystems. Ecosystem $=$ n/a pertains to formations that contain only a single ecosystem. Time-of-flow is used to weight the influence of 165 each cell in the watershed above a focal cell in the watershed-based stressor metrics.

\begin{tabular}{llcc}
\hline Formation & Ecosystem & Roughnesss & Runoff \\
\hline Alpine & n/a & 0.1 & 0.45 \\
Cliff \& Rock & All & 0.02 & 0.4 \\
Grassland \& Shrubland & All & 0.1 & 0.45 \\
Coastal Scrub-Herb & All & 0.1 & 0.45 \\
Boreal Upland Forest & All & 0.6 & 0.4 \\
Northeastern Upland Forest & All & 0.6 & 0.4 \\
Northeastern Wetland & All & 0.1 & 0.4 \\
Peatland & All & 0.1 & 0.4 \\
Stream (headwater/creek) & All & 0.02 & $\mathrm{n} / \mathrm{a}$
\end{tabular}




\begin{tabular}{|c|c|c|c|}
\hline Stream (small) & All & 0.02 & $\mathrm{n} / \mathrm{a}$ \\
\hline Stream (medium) & All & 0.02 & $\mathrm{n} / \mathrm{a}$ \\
\hline Stream (large) & All & 0.02 & $\mathrm{n} / \mathrm{a}$ \\
\hline Lentic & All & 0.02 & $\mathrm{n} / \mathrm{a}$ \\
\hline Freshwater Tidal Riverine & All & 0.02 & $\mathrm{n} / \mathrm{a}$ \\
\hline Estuarine Intertidal & All & 0.06 & 0.4 \\
\hline Marine Intertidal & All & 0.02 & 0.4 \\
\hline \multirow[t]{2}{*}{ Agriculture } & Cultivated crops & 0.2 & 0.5 \\
\hline & Pasture/hay & 0.4 & 0.45 \\
\hline \multirow[t]{15}{*}{ Developed } & Abandoned train & 0.02 & 0.6 \\
\hline & Active train & 0.02 & 0.6 \\
\hline & Culvert/bridge & 0.02 & 0.6 \\
\hline & Dam & 0.02 & 0.6 \\
\hline & Developed- high intensity & 0.02 & 0.5 \\
\hline & Developed- medium intensity & 0.04 & 0.5 \\
\hline & Developed- low intensity & 0.06 & 0.5 \\
\hline & Developed- open space & 0.1 & 0.3 \\
\hline & Local road & 0.02 & 0.6 \\
\hline & Motorway & 0.02 & 0.6 \\
\hline & Primary road & 0.02 & 0.6 \\
\hline & Secondary road & 0.02 & 0.6 \\
\hline & Tertiary road & 0.02 & 0.6 \\
\hline & Track & 0.02 & 0.6 \\
\hline & Barren land & 0.08 & 0.45 \\
\hline
\end{tabular}




\section{Appendix E. Ecological Integrity Metrics}

Links to detailed documentation for each of the ecological integrity metrics included in the ecological integrity assessment for the northeastern United States. All integrity metrics exist as

$17030 \mathrm{~m}$ rasters. Documents include a general description of the metric, considerations for the use and interpretation of the metric, derivation of the metric, including data sources and algorithm, and metadata for the distributed product. The metrics are arbitrarily grouped into broad classes for organizational purposes.

\begin{tabular}{|c|c|c|}
\hline Metric group & Metric name & Link to detailed documentation \\
\hline \multirow[t]{5}{*}{$\begin{array}{l}\text { Development } \\
\text { and Roads }\end{array}$} & Habitat loss & $\begin{array}{l}\text { http://jamba.provost.ads.umass.edu/web/lcc/DSL_documen } \\
\text { tation_habloss.pdf }\end{array}$ \\
\hline & $\begin{array}{l}\text { Watershed habitat } \\
\text { loss }\end{array}$ & $\begin{array}{l}\underline{\text { http://jamba.provost.ads.umass.edu/web/lcc/DSL_documen }} \\
\underline{\text { tation_whabloss.pdf }}\end{array}$ \\
\hline & Road traffic & $\begin{array}{l}\underline{\text { http://jamba.provost.ads.umass.edu/web/lcc/DSL_documen }} \\
\text { tation_road_traffic.pdf }\end{array}$ \\
\hline & $\begin{array}{l}\text { Mowing \& } \\
\text { plowing }\end{array}$ & $\begin{array}{l}\underline{\text { http://jamba.provost.ads.umass.edu/web/lcc/DSL_documen }} \\
\text { tation_mowplow.pdf }\end{array}$ \\
\hline & $\begin{array}{l}\text { Microclimate } \\
\text { alterations }\end{array}$ & $\begin{array}{l}\underline{\text { http://jamba.provost.ads.umass.edu/web/lcc/DSL_documen }} \\
\text { tation_edges.pdf }\end{array}$ \\
\hline \multirow[t]{3}{*}{ Pollution } & $\begin{array}{l}\text { Watershed road } \\
\text { salt }\end{array}$ & $\begin{array}{l}\underline{\text { http://jamba.provost.ads.umass.edu/web/lcc/DSL_documen }} \\
\text { tation_road_salt.pdf }\end{array}$ \\
\hline & $\begin{array}{l}\text { Watershed road } \\
\text { sediment }\end{array}$ & $\begin{array}{l}\underline{\text { http://jamba.provost.ads.umass.edu/web/lcc/DSL_documen }} \\
\text { tation_road_sediment.pdf }\end{array}$ \\
\hline & $\begin{array}{l}\text { Watershed } \\
\text { nutrient } \\
\text { enrichment }\end{array}$ & $\begin{array}{l}\underline{\text { http://jamba.provost.ads.umass.edu/web/lcc/DSL_documen }} \\
\underline{\text { tation_nutrients.pdf }}\end{array}$ \\
\hline \multirow[t]{4}{*}{$\begin{array}{l}\text { Biotic } \\
\text { Alterations }\end{array}$} & $\begin{array}{l}\text { Domestic } \\
\text { predators }\end{array}$ & $\begin{array}{l}\underline{\text { http://jamba.provost.ads.umass.edu/web/lcc/DSL_documen }} \\
\underline{\text { tation_cats.pdf }}\end{array}$ \\
\hline & Edge predators & $\begin{array}{l}\text { http://jamba.provost.ads.umass.edu/web/lcc/DSL_documen } \\
\text { tation_edgepred.pdf }\end{array}$ \\
\hline & $\begin{array}{l}\text { Non-native } \\
\text { invasive plants }\end{array}$ & $\begin{array}{l}\underline{\text { http://jamba.provost.ads.umass.edu/web/lcc/DSL_documen }} \\
\text { tation_badplants.pdf }\end{array}$ \\
\hline & Non-native & http://jamba.provost.ads.umass.edu/web/lcc/DSL_documen \\
\hline
\end{tabular}




\begin{tabular}{|c|c|c|}
\hline Metric group & Metric name & Link to detailed documentation \\
\hline & $\begin{array}{l}\text { invasive } \\
\text { earthworms }\end{array}$ & $\underline{\text { tation_earthworms.pdf }}$ \\
\hline Climate & Climate stress & $\begin{array}{l}\underline{\text { http://jamba.provost.ads.umass.edu/web/lcc/DSL_documen }} \\
\underline{\text { ation_climate_stress.pdf }}\end{array}$ \\
\hline \multirow[t]{4}{*}{$\begin{array}{l}\text { Hydrologic } \\
\text { Alterations }\end{array}$} & $\begin{array}{l}\text { Watershed } \\
\text { imperviousness }\end{array}$ & $\begin{array}{l}\underline{\text { http://jamba.provost.ads.umass.edu/web/lcc/DSL_documen }} \\
\underline{\text { tation_imperviousness.pdf }}\end{array}$ \\
\hline & Dam intensity & $\begin{array}{l}\underline{\text { http://jamba.provost.ads.umass.edu/web/lcc/DSL_documen }} \\
\underline{\text { tation_dams.pdf }}\end{array}$ \\
\hline & $\begin{array}{l}\text { Sea level rise } \\
\text { inundation }\end{array}$ & $\begin{array}{l}\underline{\text { http://jamba.provost.ads.umass.edu/web/lcc/DSL_documen }} \\
\underline{\text { ation_searise.pdf }}\end{array}$ \\
\hline & Tidal restrictions & $\begin{array}{l}\text { http://jamba.provost.ads.umass.edu/web/lcc/DSL_documen } \\
\underline{\text { tation_tidal_restrictions.pdf }}\end{array}$ \\
\hline \multirow[t]{3}{*}{ Resiliency } & Similarity & $\begin{array}{l}\underline{\text { http://jamba.provost.ads.umass.edu/web/lcc/DSL_documen }} \\
\underline{\text { tation_similarity.pdf }}\end{array}$ \\
\hline & Connectedness & $\begin{array}{l}\underline{\text { http://jamba.provost.ads.umass.edu/web/lcc/DSL_documen }} \\
\underline{\text { tation_connect.pdf }}\end{array}$ \\
\hline & $\begin{array}{l}\text { Aquatic } \\
\text { connectedness }\end{array}$ & $\begin{array}{l}\underline{\text { http://jamba.provost.ads.umass.edu/web/lcc/DSL_documen }} \\
\underline{\text { tation_aqconnect.pdf }}\end{array}$ \\
\hline
\end{tabular}




\section{Appendix F. Ecological Integrity Models}

Relative weights of component metrics (see Appendix E for links to documents describing each metric) in the composite index of ecological integrity (IEI) and index of ecological impact (ecoImpact) for each ecological formation (groups of similar ecological systems, Appendix B). Note, the weights reflect the relative importance of each metric to the composite IEI and ecoImpact indices for

180 each formation and they sum to $\sim 100 \%$ for each ecological formation. Note, climate and searise metrics are only used for computing future IEI and ecoImpact. Weights were assigned by expert teams as described below.

\begin{tabular}{|c|c|c|c|c|c|c|c|c|c|c|c|c|c|c|c|c|c|c|c|c|}
\hline $\begin{array}{l}\text { Ecological } \\
\text { formation }\end{array}$ & $\begin{array}{l}\tilde{0} \\
0 \\
\text { శี }\end{array}$ & $\begin{array}{l}\tilde{n} \\
0 \\
\frac{0}{0} \\
\frac{\pi}{3}\end{array}$ & 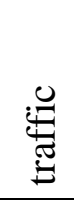 & $\begin{array}{l}3 \\
3 \\
3 \\
0 \\
0 \\
0\end{array}$ & $\mathscr{\bigotimes}_{0}^{\infty}$ & $\underset{\omega}{\tilde{\omega}}$ & 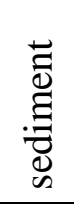 & 苞 & $\frac{\mathscr{0}}{\tilde{U}}$ & 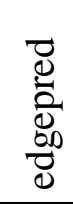 & 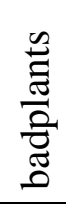 & $\begin{array}{l}\text { है } \\
0 \\
\vdots\end{array}$ & 怘 & $\begin{array}{l}\text { 节 } \\
\text { 売 }\end{array}$ & 灵 & 异 & $\begin{array}{l}\ddot{U} \\
\stackrel{\Xi}{0} \\
\stackrel{0}{0}\end{array}$ & 䒕 & $\begin{array}{l}\mathscr{n} \\
\tilde{\Xi} \\
\ddot{\omega}\end{array}$ & 종 \\
\hline Alpine & 0.0 & 0.0 & 5.3 & 0.0 & 0.0 & 0.0 & 0.0 & 0.0 & 0.0 & 0.0 & 5.3 & 0.0 & 0.0 & 0.0 & 7.1 & 7.1 & 0.0 & 25.1 & 50.0 & 0.0 \\
\hline Cliff \& Rock & 6.9 & 0.0 & 3.3 & 0.0 & 0.0 & 0.0 & 0.0 & 0.0 & 4.4 & 3.1 & 6.5 & 0.0 & 0.0 & 0.0 & 9.5 & 10.9 & 0.0 & 5.0 & 50.0 & 0.0 \\
\hline $\begin{array}{l}\text { Grassland \& } \\
\text { Shrubland }\end{array}$ & 9.0 & 0.0 & 4.5 & 0.0 & 0.0 & 0.0 & 0.0 & 0.0 & 2.2 & 4.5 & 4.5 & 2.2 & 0.0 & 0.0 & 6.7 & 11.2 & 0.0 & 5.0 & 50.0 & 0.0 \\
\hline $\begin{array}{l}\text { Coastal Scrub- } \\
\text { Herb }\end{array}$ & 7.4 & 0.0 & 4.1 & 0.0 & 0.0 & 0.0 & 0.0 & 0.0 & 3.9 & 4.5 & 3.6 & 0.0 & 0.0 & 0.0 & 10.0 & 11.3 & 0.0 & 4.9 & 50.0 & 0.0 \\
\hline $\begin{array}{l}\text { Boreal Low } \\
\text { Elevation } \\
\text { Forest }\end{array}$ & 4.5 & 0.0 & 4.5 & 0.0 & 2.2 & 0.0 & 0.0 & 0.0 & 2.2 & 4.5 & 4.5 & 4.5 & 0.0 & 0.0 & 6.7 & 11.2 & 0.0 & 5.0 & 50.0 & 0.0 \\
\hline
\end{tabular}




\begin{tabular}{|c|c|c|c|c|c|c|c|c|c|c|c|c|c|c|c|c|c|c|c|c|}
\hline $\begin{array}{l}\text { Boreal } \\
\text { Montane } \\
\text { Forest }\end{array}$ & 3.5 & 0.0 & 3.5 & 0.0 & 1.7 & 0.0 & 0.0 & 0.0 & 1.7 & 3.5 & 3.5 & 3.5 & 0.0 & 0.0 & 5.2 & 8.7 & 0.0 & 15.0 & 50.0 & 0.0 \\
\hline $\begin{array}{l}\text { Northeastern } \\
\text { Upland Forest }\end{array}$ & 4.5 & 0.0 & 4.5 & 0.0 & 2.2 & 0.0 & 0.0 & 0.0 & 2.2 & 4.5 & 4.5 & 4.5 & 0.0 & 0.0 & 6.7 & 11.2 & 0.0 & 5.0 & 50.0 & 0.0 \\
\hline $\begin{array}{l}\text { Northeastern } \\
\text { Wetland }\end{array}$ & 4.1 & 4.2 & 4.1 & 2.0 & 0.9 & 2.0 & 2.0 & 2.0 & 0.0 & 2.0 & 2.0 & 0.9 & 1.0 & 0.0 & 4.1 & 7.3 & 1.4 & 4.5 & 50.0 & 4.6 \\
\hline Peatland & 4.7 & 4.7 & 2.3 & 2.3 & 0.0 & 4.7 & 2.3 & 4.7 & 0.0 & 2.3 & 0.0 & 0.0 & 2.3 & 0.0 & 4.7 & 9.5 & 0.0 & 5.0 & 50.0 & 0.0 \\
\hline $\begin{array}{l}\text { Stream } \\
\text { (headwater/cre } \\
\text { ek) }\end{array}$ & 2.4 & 4.8 & 2.4 & 2.4 & 2.4 & 0.0 & 2.4 & 2.4 & 0.0 & 2.4 & 0.0 & 0.0 & 4.8 & 7.3 & 0.0 & 4.8 & 7.3 & 0.0 & 50.0 & 4.1 \\
\hline Stream (small) & 2.4 & 4.8 & 2.4 & 2.4 & 2.4 & 0.0 & 2.4 & 2.4 & 0.0 & 2.4 & 0.0 & 0.0 & 4.8 & 7.3 & 0.0 & 2.4 & 9.7 & 0.0 & 50.0 & 4.1 \\
\hline $\begin{array}{l}\text { Stream } \\
\text { (medium) }\end{array}$ & 2.5 & 5.1 & 2.5 & 2.5 & 0.0 & 0.0 & 2.5 & 2.5 & 0.0 & 2.5 & 0.0 & 0.0 & 5.1 & 7.7 & 0.0 & 2.5 & 10.3 & 0.0 & 50.0 & 4.1 \\
\hline Stream (large) & 2.5 & 7.7 & 2.5 & 2.5 & 0.0 & 0.0 & 2.5 & 2.5 & 0.0 & 2.5 & 0.0 & 0.0 & 5.1 & 5.1 & 0.0 & 2.5 & 10.3 & 0.0 & 50.0 & 4.1 \\
\hline Lake & 2.6 & 10.6 & 2.6 & 2.6 & 0.0 & 2.6 & 2.6 & 5.2 & 0.0 & 2.6 & 0.0 & 0.0 & 2.6 & 0.0 & 5.2 & 5.2 & 5.2 & 0.0 & 50.0 & 0.0 \\
\hline Pond & 2.6 & 10.6 & 5.2 & 2.6 & 0.0 & 2.6 & 2.6 & 5.2 & 0.0 & 2.6 & 0.0 & 0.0 & 2.6 & 0.0 & 5.2 & 7.8 & 0.0 & 0.0 & 50.0 & 0.0 \\
\hline $\begin{array}{l}\text { Freshwater } \\
\text { Tidal Riverine }\end{array}$ & 2.5 & 7.7 & 2.5 & 2.5 & 0.0 & 0.0 & 2.5 & 2.5 & 0.0 & 2.5 & 0.0 & 0.0 & 5.1 & 5.1 & 0.0 & 2.5 & 10.3 & 0.0 & 50.0 & 4.1 \\
\hline $\begin{array}{l}\text { Estuarine } \\
\text { Intertidal }\end{array}$ & 8.3 & 0.0 & 2.4 & 0.8 & 0.0 & 0.0 & 0.0 & 0.0 & 1.6 & 2.7 & 0.0 & 0.0 & 0.0 & 0.0 & 11.4 & 13.1 & 0.0 & 4.5 & 50.0 & 4.9 \\
\hline $\begin{array}{l}\text { Marine } \\
\text { Intertidal }\end{array}$ & 7.2 & 0.0 & 0.9 & 0.0 & 0.0 & 0.0 & 0.0 & 0.0 & 2.6 & 4.2 & 0.0 & 0.0 & 0.0 & 0.0 & 14.0 & 13.2 & 0.0 & 4.7 & 50.0 & 2.8 \\
\hline
\end{tabular}


We formed the following expert teams for groups of ecological formations to establish weights for the constituent metrics in the ecological models:

- Forests: The forest expert team met on 14 November 2000 to establish weights for each of the forested ecological formations. The Team consisted of eight professionals and scientists representing the USDA Forest Service, Northeast Experiment Station, Massachusetts Division of Wildlife, Connecticut College, and the University of Massachusetts, Amherst.

- Wetlands: The wetland expert team met on 13 February 2001 to establish weights for each of the wetland and freshwater aquatic ecological formations. The Team consisted of seven professionals and scientists representing Massachusetts Division of Wildlife, University of Rhode Island and University of Massachusetts, Amherst.

- Grasslands \& Shrublands: The grasslands and shrublands expert team met on 19 December 2000 to establish weights for each of the non-forested, terrestrial ecological formations (i.e., alpine, cliff and rock, grassland \& shrubland, coastal scrub-herb). The Team consisted of 12 professionals and scientists representing USG Woods Hole Coastal and Marine Science Center, MassAudubon, Massachusetts Division of Wildlife, Trustees of Reservations, and the University of Massachusetts, Amherst.

- Coastal ecosystems: The coastal expert team met on 12 May 2010 to establish weights for each of the coastal ecological formations. The Team consisted of 15 professionals and scientists representing Massachusetts Division of Wildlife, Massachusetts Department of Environmental Protection, Massachusetts Coastal Zone Management, and the University of Massachusetts. 
The final metric weights for the forest, wetlands, and grasslands \& shrublands teams were arrived at by consensus. For the coastal expert teams have been crosswalked and modified slightly over the years as the ecosystem classification, metrics and approaches changed. 


\section{Appendix G. Index of Ecological Impact.}

205 As described in the text, the index of ecological integrity (IEI) can be computed for any snapshot of a landscape and it reflects the relative intactness and resiliency of a site based on the conditions existing in that snapshot. Thus, we can compute IEI for the same landscape but at different points in time under a single land use scenario, or single landscape at the same point in time but under alternative land use scenarios. Whereas IEI is in effect a static measure of the

210 ecological integrity of a site at any point in space and time, the index of ecological impact (ecoImpact) essentially measures the change in IEI between the two snapshots of the same landscape; e.g., current versus future landscape relative to the current IEI. A site that experiences a major loss of IEI has a high predicted ecological impact of the simulated landscape changes; a loss of say 0.5 IEI units reflects a greater relative impact than a loss of 0.2 IEI units.

215 Moreover, the loss of 0.5 units from a site that has a current IEI of 0.9 for example, is much more important than the same absolute loss from a site that has a current IEI of 0.5. Thus, ecoImpact reflects not only the magnitude of loss of IEI, but also where it matters most — sites with high initial integrity.

The derivation of ecoImpact consists of rescaling the individual raw metrics, but using a

220 different rescaling procedure than used with IEI, then combining the metrics into the composite index, and then computing the final index. Each of these steps are described in the following sections.

Delta-rescaling.-The embedded use of quantile-rescaling in IEI suffers from what we refer to as the "Bill Gates" effect when used for scenario comparison. The "Bill Gates" effect occurs

225 when the value of the raw metric is decreased in a cell but it remains the highest valued cell -the quantile is unchanged. This is analogous to taking millions of dollars away from Bill Gates 
and yet he remains the richest man around. Likewise, a small absolute change in a raw metric can under certain circumstances result in a large change in its quantile, even though the ecological difference is trivial. Therefore, the use of quantile-rescaling is not appropriate if we

230 want to be sensitive to any absolute change in the integrity metrics. To address these issues, we developed delta-rescaling as an alternative to quantile-rescaling that is more meaningful when comparing among scenarios (or timesteps of a single scenario).

Delta-rescaling is rather complicated in detail. Briefly, delta-rescaling involves computing the difference in the metric from its baseline value at timestep 0 . Thus, delta-rescaling does not

235 involve comparing the condition of a cell to ecologically similar cells of the same ecological system, but rather comparing the condition of a cell to itself under the baseline (e.g., timestep 0) condition. These delta-rescaled metrics can then be combined in a weighted linear combination to form a composite delta ecological integrity index, and this composite index can be multiplied by the ecological integrity index (IEI) of the cell under the baseline scenario to derive an

240 "impact" index (ecoImpact), as described below.

Unfortunately, since the raw metrics are on different scales, we can't simply compute the delta between the current and future timesteps, as the raw deltas would also be on different scales. But in order to combine the metrics into a composite index they must be placed on the same or similar scale. A simple solution would be to range rescale each raw metric so that it 245 ranges $0-1$. However, range rescaling is very sensitive to extreme values and most of the raw metrics have positively or right-skewed distributions containing relatively few very large values. To address this issue we instead use a rather complicated rescaling procedure, as follows: 
1) For each raw stressor

250 metric at the fullest geographic extent, we find its $90^{\text {th }}$ quantile benchmark and apply a logistic transformation such that this benchmark ends up with a score of 0.95 , as follows:

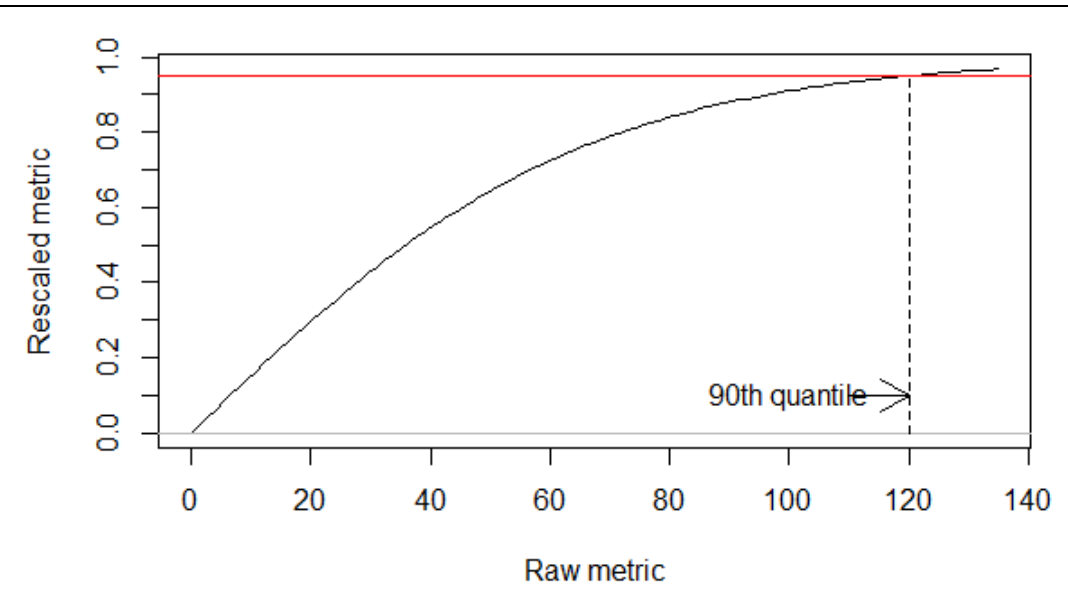

Figure G1. Logistic transformation of a raw metric scaled 0135 with a $90^{\text {th }}$ quantile of 120 as used in delta-rescaling. The rescaled metric ranges from $0 \sim 1$ with a value of 0.95 (red line) for the $90^{\text {th }}$ quantile.

$$
\begin{aligned}
\text { rescaled.metric } & =\left(\frac{1}{e^{(- \text {raw.metric } / s)}+1}\right) * 2-1 \\
s & =\frac{- \text { benchmark }}{\ln (2 / 1.95-1)}
\end{aligned}
$$

260 The end result is that each rescaled stressor metric ranges from $0 \sim 1$ (Fig. G1).

2) For the aquatic connectedness (aqconnect) metric, we compute the maximum value of aqconnect (aqcmax) for each cell by running it without the anthropogenic settings variables (i.e., as if there were no road-stream crossings and dams), find the $95^{\text {th }}$ quantile of aqcmax, and rescale the metric as follows:

$$
\text { rescaled.aqconnect }=\frac{0.95}{\text { quantile }(\text { aqcmax }, 0.95)}
$$

The end result is that rescaled aqconnect ranges from $0 \sim 1$. 
3) For the connectedness and similarity metrics, which scale naturally from $0 \sim 1$ (for a highly similar and connected neighborhood), we keep them in their raw scale form.

265 After rescaling each of the integrity metrics, we compute the difference (or delta) between the baseline (e.g., timestep 0) value and the alternative (e.g., future landscape) value. These delta-rescaled metrics have a theoretical range of -1 to 1 . A value of -1 indicates the maximum potential loss of IEI (e.g., a cell with the maximum IEI gets developed), whereas a value of +1 indicates the maximum potential increase in IEI (e.g., a developed cell is restored to the

270 maximum IEI). These delta-rescaled metrics are combined into a composite index as described next.

Ecological integrity models.—After delta-rescaling, the metrics are all on approximately the same scale. The next step is to combine the delta-rescaled metrics into a composite index. To do this we apply the ecological integrity models described in the text for IEI.

275 Computing the final index.-After combining the delta-rescaled metrics in a weighted linear combination, we multiply the value by the baseline value of IEI (e.g., the value in timestep 0). In this manner, roughly speaking the index is designed to reflect the percentage change in IEI (as estimated via delta-rescaling) where it matters most — areas with high initial IEI. For example, the ecological impact is relatively greater (and thus more important) for a cell with a delta score 280 of -0.4 and an initial IEI of 1 compared to a cell with the same delta score but an initial IEI of 0.5. The final index has a theoretical range of -1 (when a cell with initial IEI=1 gets developed) to +0.25 (when a cell with initial $I E I=0.5$ gets restored to the maximum IEI), but in practice it will rarely approach the upper limit and only infrequently will it even be $>0$ (denoting an improvement in IEI). In addition, because IEI is scaled by ecological setting or ecosystem and 
285 geographic extent, as described in the text for IEI, ecoImpact also varies depending on the geographic extent used to scale IEI for the baseline condition.

Interpreting ecoImpact.—As described above, ecoImpact is a composite index derived from the individual intactness and resiliency metrics (Table 2 in the main text); it is a synoptic measure of the predicted local ecological impact of landscape change and represents the

290 principal result of our coarse-filter assessment of the ecological impact of the forecasted landscape changes. In contrast to IEI, ecoImpact is delta-scaled to reflect the percentage loss of IEI from cells of high baseline IEI largely independent of their ecological setting or ecosystem, and is only modestly affect by the geographic extent of the analysis. Briefly, as described in the previous sections, the individual raw metrics are first delta-rescaled, then combined in a

295 weighted linear function specific to each ecological setting or ecosystem (e.g., Appendix F), and then multiplied by the baseline IEI to produce the final ecoImpact index for each landscape comparison. The end result is that a cell with maximum baseline IEI (1) that loses all of its IEI $(1 \rightarrow 0)$ in the alternative landscape (e.g., projected future landscape) gets a value of -1 , indicating the maximum possible ecological impact. Conversely, a cell that experienced no change in IEI 300 would get would get a value of 0 , indicating no ecological impact. Lastly, a cell that experienced a gain in IEI would get a positive value that has an upper limit of 0.25 , although in practice positive values are rare and typically very small.

It is important to recognize the relative nature of ecoImpact and how it differs from IEI. Whereas IEI is always relative to the ecological system of a cell and the geographic extent of the 305 scaling, the ecoImpact of a cell is always relative to itself (regardless of ecosystem or landscape extent) under the baseline condition. The ecoImpact of a cell reflects how much the integrity of the cell (as measured by IEI) decreases as a result of the forecasted landscape changes relative to 
the initial or baseline IEI of the cell. Thus, ecoImpact compares a cell to itself - e.g., the change in integrity over time - whereas IEI compares a cell to other cells of the same ecological setting

310 or ecosystem within the specified geographic extent. While this interpretation is roughly correct, it is not entirely so. ecoImpact involves multiplying the weighted linear combination of deltarescaled metrics by the baseline IEI. Therefore, technically speaking the ecological setting or ecosystem of the cell and the geographic extent of the analysis have an effect on the final computed value, but the role of ecosystem membership and geographic extent is relatively minor

315 compared to IEI. Because of the relative nature of ecoImpact, it can be used as a comparative index to compare one site to another or to compare the same site to itself under different landscape change scenarios. 